A Journal of Agricultural Science Publisbed by the California Agricultural Experiment Station

HOST ORGANS ATTACKED BY BACTERIAL CANKER OF STONE FRUITS

EDWARD E. WILSON and WM. B. HEWITT

FACTORS AFFECTING DEVELOPMENT OF THE BACTERIAL CANKER OF STONE FRUITS EDWARD E. WILSON

SOME FACTORS AFFECTING THE SUSCEPTIBILITY OF PLANTS TO FIRE BLIGHT

H. EARL THOMAS and P. A. ARK 
FACTORS AFFECTING DEVELOPMENT OF THE BACTERIAL CANKER OF STONE FRUITS

\author{
EDWARD E. WILSON
}





\title{
FACTORS AFFECTING DEVELOPMENT OF THE BACTERIAL CANKER OF STONE FRUITS ${ }^{1}$
}

\author{
EDWARD E. WILSON ${ }^{2}$
}

Bacterial canker of Prunus, caused by Phytomonas cerasi (Griffin) Bergey et $a l .{ }^{3}$ has been studied by the writer, with some interruptions, for the past seven years. Certain phases, including the serious limbcanker stage, have been described from time to time (15-18).

This article discusses how various factors affect canker activity after infection is established.

\section{SEQUENCE OF EVENTS IN DEVELOPMENT OF BACTERIAL CANKER UNDER ORCHARD CONDITIONS}

Stages in the Activity of Cankers.-Although a general description of canker development is in print (16), later discussion will be clarified if the sequence of changes during canker activity is described in detail at this point.

An established canker will be taken as an example, and its development from early autumn to summer will be followed. This canker, present in the tree in early autumn, arose from an infection the previous winter or spring. It is a roughly elliptical area of dead bark, its margins grading away either into healthy tissue or, more frequently, into a series of reddish-brown streaks, which form a zone sometimes several inches wide at the apices of the necrotic center. In early autumn the canker appears inactive, the tissue involved being dry with no signs of water-soaking along the margins. The lateral margins of the canker may be delimited by a roll of new tissue, the outer layers of which are essentially callus in nature.

The nature of the reddish-brown streaks present at the apical margins is discussed in a later section. Nothing further will be said about them here except that they are called "dormant streaks" to distinguish them from the less noticeable, dull-brown, water-soaked streaks occurring at the margins of active cankers. The designations dormant and active are used because such streaks are characteristic, respectively, of dormant (or quiescent) and active cankers.

\footnotetext{
${ }^{\mathrm{t}}$ Received for publication June 14, 1938.

${ }^{2}$ Associate Plant Pathologist in the Experiment Station.

${ }^{3}$ The status of Phytomonas cerasi as a separate species is in question $(15,18)$. Pending further work, however, the writer prefers to retain the species name.

"Italic numbers in parentheses refer to "Literature Cited," at the end of this paper.
} 
Active streaks presumably are the path along which the bacteria advance. They are more numerous nearest the center of the canker. Thus the bacteria do not at first invade all the tissue along the advancing margins. Later, however, they do involve the tissue between those streaks nearest the center of the canker; but when the cankers stop extending in the summer, a wide zone of partially invaded tissue frequently remains at the upper ends of the necrotic area. This description, of course, is typical only of cankers in plums. In apricot and cherry the complete involvement of diseased tissue tends more often to keep pace with the advancing margins. Hence, as noted in an earlier article (16), cankers in these hosts often differ from cankers in the plum in being well-delimited, uniformly necrosed areas, with little partially invaded tissue at the margins. In the plums, on the other hand, the partially invaded zone, though not always easily distinguished from the healthy tissue while cankers are active, is generally present and noticeable after cankers become inactive. The varying appearance of this zone among different plum varieties is the subject for a later section.

With the gross characters of cankers in mind, the important landmarks of canker activity will be described. Activity of a previously inactive canker is noticeable because the margins of the uniformly dead center appear poorly defined and watery. In addition, the tissues between the dormant streaks partake of the same watery appearance. Next, the partially invaded margins of the cankers will begin to extend. This series of events is usually noticeable sometime in late October or in November.

Activity continues during midwinter; but invaded tissue may manifest the disease only by the presence of a few slightly brown active streaks. Sometime in early spring or late winter the tissue invaded during the winter rapidly turns darker brown and watery and develops a sour smell. Meanwhile the cankers will be seen to advance very rapidly in all directions, particularly upward and downward. Because the developments during this stage are rapid, a casual observer would believe that the cankers had originated and had spread throughout the bark of a tree in a period of only 3 or 4 weeks. In fact, growers who have seen this phenomenon frequently believe that disease development is confined entirely to spring and early summer.

The period of most rapid canker development may extend from about March 1 until late April. Thereafter there is a slowing-down and eventually an apparent cessation of extension. The first noticeable sign of this phenomenon appears in the uniformly necrosed margins. During activity the margins of the completely invaded tissue grade insensibly into healthy tissue, but when activity wanes they become well defined, par- 
ticularly the lateral margins. The next sign of cessation of activity is in the streaks at the apices of cankers. These streaks, more or less diffuse during the active stage, begin also to take on well-defined margins and gradually change from a dull to a reddish brown. As shown later, the relative proportions of streaks eventually undergoing this change varies among cankers in the same tree and especially among cankers in trees of different varieties.

We have now traced canker development from a stage of quiescence in early autumn, through a stage of activity in late autumn, winter, and spring, back to a stage of quiescence in early summer. Throughout the

TABLE 1

Occurrence of Bacteria in Different Parts of Cankers

\begin{tabular}{|c|c|c|c|}
\hline Areas of cankers from which isolations were made & $\begin{array}{l}\text { Number } \\
\text { of cankers } \\
\text { studied }\end{array}$ & $\begin{array}{c}\text { Number } \\
\text { of isolations } \\
\text { made }\end{array}$ & $\begin{array}{c}\text { Per cent } \\
\text { of } \\
\text { isolations } \\
\text { yielding } \\
\text { bacteria }\end{array}$ \\
\hline Zone of streaks at upper margins of inactive cankers. & 14 & 70 & 73 \\
\hline Zone of streaks at margins of active cankers........ & 8 & 40 & 88 \\
\hline Recent uniformly necrosed tissue of active cankers. . & 23 & 115 & 39 \\
\hline Uniformly necrosed margins of inactive cankers.... & 17 & 85 & 24 \\
\hline Uniformly necrosed centers of inactive cankers. . & 9 & 45 & 22 \\
\hline
\end{tabular}

summer, cankers remain inactive; or, at least, extension is so slow as to be undetectable. Not all, however, follow an identical course, for many fail to become active in the autumn. In one orchard of Duarte plums the percentage of cankers becoming active a second season varied from 30 to 65 in different years.

Relation of the Bacterial Population to Stages of Canker Activity.Presumably the rise and fall of canker activity indicates corresponding fluctuations of bacterial activity in the diseased tissue. Freehand sections of diseased tissue in different stages of involvement have manifested tremendous differences in the bacterial population. According to one attempt at a semiquantitative determination, between late January and mid-February the number of bacteria increased 1,000 per cent. This increase occurred while diseased areas were undergoing rapid necrosis; the bacteria were invading all tissue of areas earlier only partially invaded. Apparently, furthermore, once the tissue is completely necrosed the bacteria decrease in numbers. Table 1 summarizes the results of isolations from different parts of cankers. In making the isolations, bits of diseased tissue were removed from five places in each part of the canker and were dropped in nutrient broth. Thus 70 isolations were made from the zone of streaks at upper margins of 14 inactive cankers. Of 
these isolations 73 per cent yielded bacteria, whereas only 24 per cent of those from the uniformly necrosed margins of inactive cankers and a correspondingly low per cent of those from uniformly necrosed centers of inactive cankers yielded bacteria. Viable bacteria were obtained from 88 per cent of isolations from the zone of streaks at the margins of active cankers, but were found in only 39 per cent of isolations from recent uniformly necrosed tissue of active cankers. Not only have these results since been confirmed, but bacteria have been found as much as 2 inches beyond the visible apices of extremely active diseased areas. These findings agree with the earlier statement that the bacteria do not at first invade all tissue along the paths of advance.

Obviously, the foregoing series of isolations did not reveal the number of bacteria present, but did show the relative frequency with which viable organisms occurred in tissues differing in degrees of involvement. According to microscopic examinations, as well as the semiquantitative studies mentioned above, the peak of bacterial population is reached during the spring when the cankers are enlarging most rapidly ; as activity wanes, so do the bacterial numbers. Judging from the infrequent occurrence of viable bacteria in margins of those cankers that have undergone uniform necrosis up to the visible limits of invasion, such cankers may fail to become active the following season. In cherry bacteriosis in England, Wormald (20) has noticed that cankers surrounded by a border of callus did not contain viable bacteria during July and August, whereas cankers not bordered by callus contained bacteria. Presumably, such cankers as did not yield bacteria in late summer would not again become active. Wormald neither mentions this possibility nor specifies at what period of the year naturally occurring cankers first become active under conditions in England. He does, however, say that inoculations produced cankers only when made after leaf fall in the autumn and that cankers did not increase in size after June. Regarding the plum disease in California, this much can be added: diseased areas that have entered the inactive state with little or no partially invaded tissue at the edge of their uniformly necrosed margins contain bacteria less frequently than do areas with a wide zone of such tissue at the margins. The apices of cankers of the former type are bordered by callus more frequently than those of the latter type. Hence, in a limited way, visible canker characteristics during the summer indicate the presence or absence of viable bacteria.

A somewhat similar situation exists with the fire blight disease. Opinions conflict regarding the frequency with which Erwinia amylovora (Bur.) Bergey et al. survives the winter in the different types of cankers, 
designated by Tullis (12) as determinate and indeterminate. Brooks (2) and Miller ( 7 ) believe the indeterminate type to be the most frequent holdover source, but Rosen (10) does not concur.

\section{EXPERIMENTAL EVIDENCE ON THE EXTENSION OF CANKERS DURING DIFFERENT SEASONS OF THE YEAR}

To obtain evidence, beyond that published earlier (16), of the comparative rates at which cankers extend during different seasons of the year, inoculations were made at intervals throughout most of two years. Duarte plum trees were employed. Results of other, less systematic trials on President plum and Bing cherry do not differ essentially from those obtained in Duarte.

Methods.-The method of inoculating the bacteria into the trees was similar to that of most earlier experiments $(16,18)$ : a sterile needle was passed tangentially through the bark, and a few drops of water suspension of the bacteria were injected into the holes with a hypodermic needle. Preliminary tests showed no particular necessity for sealing the inoculation holes during most of the year. From 50 to 70 inoculations were made into 5 trees at each time.

In securing data it was necessary to remove the outer bark, which rendered the canker useless for further measurements. Thus when a second set of measurements was required of the same series, 35 to 50 additional inoculations were made. Length and width of the diseased area in the bark were recorded. The width of the canker was not used in compiling the data, since it varied with the length of the tangential path of the needle through the bark. Sometimes the disease had extended along the cambium as a few narrow, brown streaks for a considerable distance beyond the limits of the bark lesion; but as these streaks varied along inoculations made in the same trees on the same day, they were disregarded in making measurements.

The data for comparative purposes were usually taken 20 days after inoculation and are expressed in millimeters as the average length of the cankers measured.

Results.-The first series of inoculations of 1934 made (fig. 1) on September 15 resulted in small lesions averaging about 5 millimeters long, and those resulting from October 20 inoculations were only slightly larger. The November 28 inoculations, however, produced cankers averaging 66 millimeters long. Canker extension, slow in mid-December, increased as spring approached, reaching a maximum on April 19. After this date, each succeeding inoculation produced progressively smaller 
diseased areas until, by June 15, lesions of the same length as those developing in September were secured.

Inoculations begun on September 4, 1935 (fig. 2), were made at intervals until July 18, 1936. The symptoms produced in September, 1935, were more extensive than those produced in September, 1934, but mark-

\begin{tabular}{|c|c|c|}
\hline $\begin{array}{l}\text { Date of } \\
\text { inoculation }\end{array}$ & $\begin{array}{l}\text { Mean temp. of } 20 \\
\text { days following inoc. }\end{array}$ & 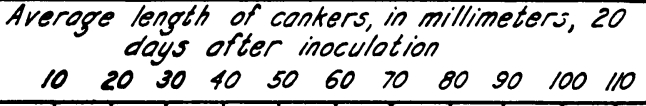 \\
\hline Sept. 15 & $67^{\circ} \mathrm{F}$ & \\
\hline oct. 20 & $59^{\circ}$ & \\
\hline Nor. 28 & $51^{\circ}$ & \\
\hline Dec. 18 & $44^{\circ}$ & \\
\hline Jon. 10 & $46^{\circ}$ & \\
\hline San. 23 & $48^{\circ}$ & \\
\hline Feb. /I & $48^{\circ}$ & 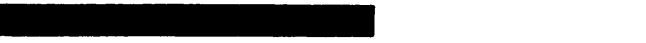 \\
\hline $\mathrm{Feb} .27$ & $48^{\circ}$ & \\
\hline March 26 & $55^{\circ}$ & . \\
\hline April 4 & $55^{\circ}$ & \\
\hline April 19 & $60^{\circ}$ & \\
\hline April 27 & $58^{\circ}$ & \\
\hline May 10 & $62^{\circ}$ & \\
\hline May 28 & $70^{\circ}$ & \\
\hline June 15 & $76^{\circ}$ & \\
\hline
\end{tabular}

Fig. 1.-Development of bacterial canker from inoculations made at various times through the autumn, winter, and spring of 1934-35. The decline in the rate of canker extension as summer approaches, indicated by these data, parallels the observed cessation of activity in naturally occurring cankers. The slow canker expansion in midwinter is apparently the result of low temperature.

edly less extensive than those resulting from inoculation on October 8. From late October to mid-December results were variable, comparatively large cankers developing in all except the December 19 inoculations. During January and February the rate of canker extension increased, reaching a maximum in late February. The rate of extension was maintained at a relatively high level during March and April but began to wane in May. Lesions averaging less than 10 millimeters long resulted from inoculations June 5, July 1, and July 18. 
To obtain further data on the comparative rate of elongation over the 20-day period, cankers produced by certain interval inoculations reported in figures 1 and 2 were measured at the end of 10 days and again at the end of 20 days. Since the cankers measured at the end of 10 days were necessarily destroyed in obtaining the data, a second set in the same inoculation series was measured at the end of 20 days. The averages obtained from these two sets of measurements appear in figures 3 and 4.

\begin{tabular}{|c|c|c|c|c|c|c|}
\hline $\begin{array}{l}\text { Date of } \\
\text { inoculation }\end{array}$ & $\begin{array}{l}\text { Mean temp of } 20 \\
\text { days following inoc. }\end{array}$ & $\begin{array}{c}\text { Averoge length } \\
10\end{array}$ & $\begin{array}{c}\text { of conkers, in m } \\
20 \quad 30\end{array}$ & 40 & $\begin{array}{l}55 \\
50\end{array}$ & $\begin{array}{l}\text { inoculation } \\
60\end{array}$ \\
\hline Sept 4 & 69 of & & f & & & \\
\hline Sept 21 & $67^{\circ}$ & & & & & \\
\hline oct 8 & $59^{\circ}$ & & & & & \\
\hline oct 26 & $49^{\circ}$ & & & & & \\
\hline Nor 2 & $50^{\circ}$ & & & & & \\
\hline Nor 30 & $16^{\circ}$ & & & & & \\
\hline Dec 4 & $45^{\circ}$ & & & & & \\
\hline $\operatorname{Dec} 19$ & $15^{\circ}$ & & & & & \\
\hline $\operatorname{San} 20$ & $47^{\circ}$ & & & & & \\
\hline Feb. 5 & $50^{\circ}$ & & & & & \\
\hline Feb. 26 & $58^{\circ}$ & & & & & \\
\hline March 4 & $56^{\circ}$ & & & & & \\
\hline Morch 23 & $54^{\circ}$ & & & & & \\
\hline April 22 & $63^{\circ}$ & & & & & \\
\hline May II & $66^{\circ}$ & & & & & \\
\hline June 5 & $72^{\circ}$ & & & & & \\
\hline July I & $76^{\circ}$ & & & & & \\
\hline
\end{tabular}

Fig. 2.-Development of bacterial canker from inoculations made at various times through the autumn, winter, and spring of 1935-36. Here again is noticed a decline in the rate of canker extension as summer approaches.

As figure 3 shows, cankers resulting from the January 10, 1935, inoculation had by January 20 extended an average of 15 millimeters and by January 30 had apparently extended an additional 15 millimeters. In other words, they had extended slowly but uniformly during the 20 days. We note, furthermore, in the successive inoculations made between January 10 and April 19, a progressive increase in the length the cankers attained during the 20 days after inoculation, but a progressive decrease in the increment of growth during the last 10 days of the period. 'Those resulting from April 19 inoculations apparently extended rapidly for 10 days or less and then stopped, or extended so slowly as to be undetectable in the measurement data. Likewise, cankers produced by the 
May 10 inoculation extended for 10 days or less, though less rapidly than those produced by April 19 inoculations, and then stopped.

The data secured in 1935-36 (fig. 4) agreed in general with those of the former year. Inoculations before October 8 produced small cankers, which apparently extended during the first 10-day period after inoculation and then stopped. On the other hand, inoculations between October 8 and March 4 produced in 10 days cankers of somewhat greater length,

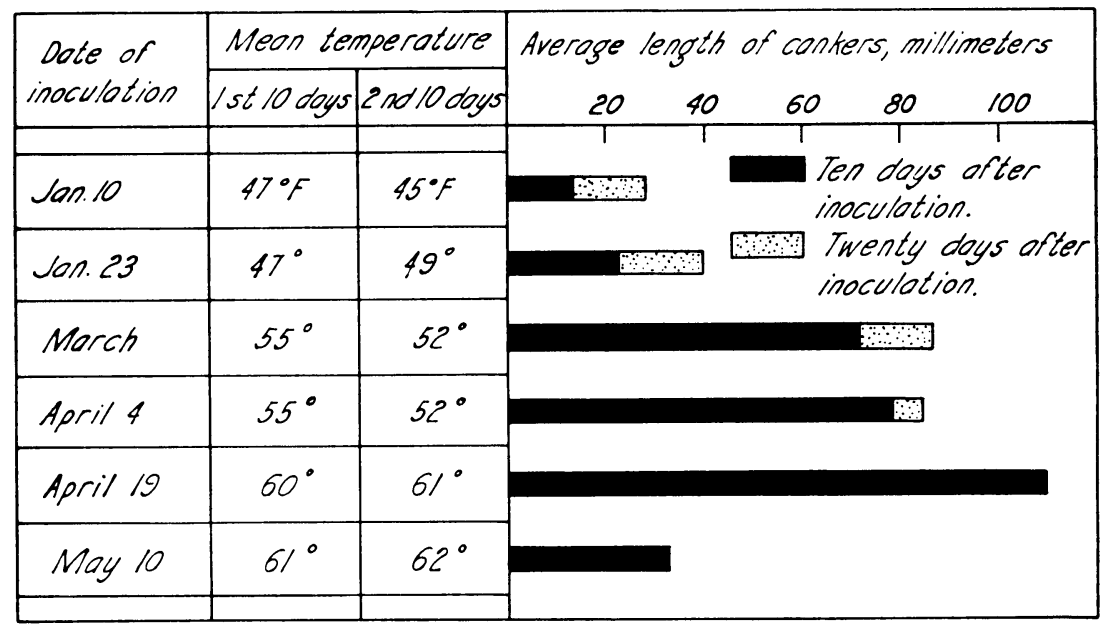

Fig. 3.-Comparative rate of expansion of cankers during the winter and spring of 1934-35. The rate of canker extension for 20 days after inoculation varied; during winter it was more uniform, though not as rapid, as during spring.

which continued to extend. But for inoculations made on April 22 or thereafter, all recorded canker extension occurred in the first 10 days, and none in the second 10.

Discussion of Inoculation Results. - Should the results in figures 1 and 2 and those published earlier (16, table 5, p. 116) be plotted, the conformity of the curves would be strikingly similar in major aspects. All the curves are low in early autumn, rise to sudden maxima in late autumn, then decline in midwinter. In early spring again, a second maximum in each curve is apparent; then follows a period when the curves decline to a low point in early summer.

The earlier interpretation of such data tended to discount the importance of the late autumn maximum; but the consistency with which that maximum occurred in three years' results with plum (including those published earlier), and in other results obtained by less systematic inoculations into cherry, have forced the conclusion that it is significant. Since it occurs very near the beginning of autumnal activity in estab- 
lished, naturally occurring cankers, it probably results from the same factors that govern renewal of canker activity. In all cases, however, the period during which cankers can extend rapidly in late autumn seems relatively short. Contrasting the duration of rapid canker activity in autumn with that in spring, we find that the latter, although varying

\begin{tabular}{|c|c|c|c|c|c|c|}
\hline \multirow{2}{*}{$\begin{array}{l}\text { Date of } \\
\text { inoculation }\end{array}$} & \multicolumn{2}{|c|}{ Mean temperature } & \multicolumn{4}{|c|}{ Average length of conkers, millimeters } \\
\hline & 1 st 10 days & $2 n d 10$ days & 20 & 30 & 40 & 50 \\
\hline & & & & $T$ & $T$ & T \\
\hline Sept. 4, 1935 & $67 \%$ & $7 / \circ F$ & & & & \\
\hline Sept. 21, 1935 & $68^{\circ}$ & $67^{\circ}$ & & & & \\
\hline Oct. 8,1935 & $61^{\circ}$ & $59^{\circ}$ & & & & 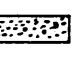 \\
\hline Nov 10,1935 & $50^{\circ}$ & $48^{\circ}$ & & & & \\
\hline Nov. 30,1935 & $48^{\circ}$ & $45^{\circ}$ & & \%? & & \\
\hline Dec. 4,1935 & $48^{\circ}$ & $43^{\circ}$ & 觕 & & & \\
\hline Jan. 20,1936 & $50^{\circ}$ & $44^{\circ}$ & & 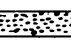 & & \\
\hline Feb. 26,1936 & $56^{\circ}$ & $59^{\circ}$ & & & 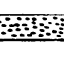 & \\
\hline March 4, 1936 & $58^{\circ}$ & $56^{\circ}$ & & S & 䠌 & \\
\hline April 22,1936 & $60^{\circ}$ & 65 & & & & \\
\hline June 5, 1936 & $68^{\circ}$ & $75^{\circ}$ & & & ys ar & \\
\hline July l, 1936 & $73^{\circ}$ & $78^{\circ}$ & : & Twen & days & ter \\
\hline Suly 18, 1936 & $79^{\circ}$ & $78^{\circ}$ & & & & \\
\hline
\end{tabular}

Fig. 4.-Comparative rate of expansion of cankers during autumn, winter, and spring of 1935-36. From late autumn until early spring, the rate of canker extension for 20 days after inoculation appeared to be more uniform than during early autumn or late spring.

from year to year, usually covers a longer period. For an example of this variation, compare the periods of maximum canker development during the springs of 1935 and 1936. The increased activity as spring approaches, as indicated by the experimental results, has its observable counterpart in the greatly accelerated springtime movement of naturally occurring cankers, mentioned in the foregoing section.

At their two extremes we find that curves of the three years' results again coincide closely. This evidence, together with field observations, 
proves an almost entire cessation of canker extension during the summer and early autumn months. Hence, activity of the cankers is confined to late autumn, winter, spring, and early summer, and thus exhibit an interesting seasonal aspect. The remainder of this paper will examine factors that might explain the rise and fall of canker activity.

Differences in the comparative rate at which cankers, resulting from inoculations at different times of the year, extended during two 10-day periods after inoculation (figs. 3 and 4 ) apparently indicate that some factor, or factors, operated to check canker extension even before the springtime maximum of activity was reached (April 19, 1935, and February 26, 1936). Apparently the factor did not exert such a limiting influence between late autumn and early spring as in early autumn and late spring. If the decline in length of cankers resulting from inoculations after the springtime maximum is caused by the same factor, or factors, which before and during the springtime maximum caused a decline in activity, then the factor must have exerted more influence as spring passed and summer approached. In other words, the ability of the factor to limit canker elongation became progressively greater.

\section{RELATION OF TEMPERATURE TO RATE OF CANKER EXTENSION}

An examination of the mean temperature prevailing during the 20 days after each series of inoculations noted in figures 1 and 2 will at once suggest that low temperatures during midwinter retarded canker development. A similar relation was found in the earlier work (16), where for example a lowering of mean temperature from $70^{\circ} \mathrm{F}$ after the October 31 inoculations, was accompanied by a correspondingly great decrease in canker extension. Likewise, a mean temperature of $45^{\circ}$ after the February 2 inoculations was accompanied by the formation of small lesions; but when the mean temperature following the March 8 inoculations was $57^{\circ}$ much larger cankers developed.

As figure 1 of the present paper shows, the autumnal maximum of canker development occurred in inoculations made November 28. The temperature for 20 days after this date averaged $51^{\circ} \mathrm{F}$. The next series of inoculations, December 18, developed rather small cankers under average temperatures of $44^{\circ}$.

Although data obtained of canker development during midwinter, 1935-36 (fig. 2) are variable, nevertheless they suggest that canker development was slower during the coldest part of the winter than during the higher temperatures of late fall or early spring.

Results of the following experiment show, apparently, an effect of 
temperature on canker extension in winter. On January 10, 1935, and again on January 23, 1935, inoculations were made on the north and south sides of cherry limbs that were growing in an essentially vertical position. Measurements of the January 10 series on February 21 gave for cankers on the south side an average length of 54 millimeters; those on the north side, 30 millimeters. In measurements of the January 23 series on February 27, cankers on the south side of limbs averaged 68 millimeters ; those on the north side, 20 millimeters. Although the mean air temperature was $49^{\circ} \mathrm{F}$ throughout both experiments, the temperature of the surface of the bark was doubtless greater on the south side than on the north side of the limb.

According to earlier experiments (16), when potted dormant trees were inoculated and held at controlled temperatures, $65^{\circ}-70^{\circ} \mathrm{F}$ was more favorable to canker extension than $50^{\circ}$, and $50^{\circ}$ was definitely more favorable than $36^{\circ}$. In a similar experiment in which potted dormant trees were inoculated and held at $36^{\circ}, 41^{\circ}, 50^{\circ}, 60^{\circ}$, and $70^{\circ}-73^{\circ}$, the last-named temperature was the most favorable for canker extension during the first 3 weeks. Soon thereafter, however, the trees started to grow; and 6 weeks after inoculation, examinations showed the diseased areas to be buried beneath new host tissue. Apparently the cankers had made no further progress after 3 weeks. Trees held at $60^{\circ}$, on the other hand, had started to grow but had not buried the cankers. By the end of 6 weeks, larger cankers were present in these trees than in those held at $70^{\circ}-73^{\circ}$ or at the lower temperatures.

One experiment with potted trees in full leaf was carried out at a controlled temperature of $52^{\circ} \mathrm{F}$ and also in a greenhouse where the temperature fluctuated between $72^{\circ}$ and $75^{\circ}$. As with all the experiments described above, the culture had been tested in orchard trees a few weeks earlier and had proved capable of producing large cankers. To prevent drying out of the inoculations the needle punctures were covered with strips of "Parafilm," a material used to some extent to reduce desiccation of tubed culture media. Upon examination of the trees at the end of 2 weeks, only 3 of the inoculations were found to have produced cankers, and these were less than 10 millimeters long. No effect of temperature was noticeable. In this case, according to the other controlled experiments, the highest temperature $\left(72^{\circ}-75^{\circ}\right)$ was not above the optimum for canker development, but was within a range more favorable to the disease than the lower temperature $\left(52^{\circ}\right)$; yet no differential effect was noticeable. The trees, in leaf in this experiment, were dormant in the other experiments. Rather than anticipate certain information to be presented later in the paper, the implications of these results will not be discussed here. 
To determine whether temperature caused the development of smaller cankers during early autumn and late spring than during late autumn and early spring is more difficult. The 1934 inoculations (fig. 1) made on September 15 and October 20, for example, produced comparatively small lesions. The mean temperatures following these inoculations were $67^{\circ}$ and $59^{\circ} \mathrm{F}$ respectively. In 1935 , furthermore, inoculations (fig. 2) on September 4 and September 21, when the mean temperatures were $69^{\circ}$ and $67^{\circ}$ respectively, also produced comparatively small cankers. These temperatures were all below that $\left(70^{\circ}-73^{\circ}\right)$ at which rapid initial canker extension occurred in controlled-temperature experiments. Since, however, the maximum temperatures after inoculation were above $70^{\circ}-$ $73^{\circ}$, we cannot rightfully compare the conditions of the two experiments. Since equipment has not been available for maintaining constant temperatures above $73^{\circ}$, little is known as to the optimum or maximum for canker extension. In an attempt to determine the effect of high temperatures under orchard conditions, Duarte plum, President plum, and Bing cherry were inoculated on May 24, 1937. The mean maximum temperature for the following 8 days was $89^{\circ}$; the mean minimum, $51^{\circ}$. During this time comparatively small cankers were produced in Duarte plum, but much larger ones in President plum and Bing cherry, although not so large as those produced in the same trees earlier in the spring. In such an experiment the unavoidable difficulty is to evaluate the effects of the wide diurnal temperature fluctuation. Possibly, had the temperature remained constantly at $89^{\circ}$, even smaller cankers would have developed in President plum and Bing cherry. One may logically conclude, on the other hand, that high temperature alone did not cause the differences in size of lesions between Duarte plum and the other two species. Some other factor must have been operating to restrict canker extension. Later, evidence is presented to show that at other times of the year canker development differs among the three hosts in the manner just indicated. Apparently, therefore, these differences are caused by conditions inherent in trees of the different types.

According to data in the foregoing section, cankers extended in spring and autumn at different rates during two 10-day periods after inoculation. In some cases the mean temperature varied little during successive 10-day periods. Thus on April 19, 1935 (fig. 3), the mean temperature of the first 10 days after inoculation was $60^{\circ} \mathrm{F}$, and canker extension was rapid; but during the second 10 days, when the mean temperature was $61^{\circ}$, no canker development was noticeable. Similar instances are seen in figure 4. Rate of canker extension during late autumn and winter was, on the other hand, more uniform during the two periods. Despite the lack 
of data on optimum temperature for disease activity, there is no justification for concluding that temperature wholly explains the unequal extension noted above. More likely, some other factor was operative only during certain times of the year. The trend of the data in figures 3 and 4 suggests that this factor became influential at a time (early spring) when increasing temperature favored increased canker activity. Note, for example, the coincidence between increased rate of canker extension during the first 10 days and the decreased rate of extension during the second 10. In 1935 the springtime maximum of canker activity was reached on April 19 (fig. 3), but the factor had so marked an influence as to prevent canker extension longer than 10 days after inoculation. When on May 10 inoculations were again made, canker extension was a fraction of that in April. Interestingly enough, the mean temperature after the April 19 and May 10 inoculations was the same.

The data, therefore, fail to reveal a direct effect of temperature on the decreased rate of canker elongation apparent (figs. 1 and 2) after springtime maximum ; nor is there convincing evidence that the lack of canker development in early autumn was the direct result of unfavorable temperature.

\section{RELATION OF CERTAIN OTHER EXTERNAL FACTORS TO CANKER DEVELOPMENT}

Effect of Soil Fertility.-That soil fertility, especially as regards nitrogen, might affect bacterial canker was brought to the writer's attention in the spring of 1934. The disease, having attacked a planting of twoyear-old Albright peach trees, was causing noticeably less damage to a number of trees fertilized in the winter with 2 pounds of ammonium sulfate each. In April, as soon as the situation was noted, the remaining unfertilized trees were grouped according to severity of infection. Those already girdled by the cankers, being obviously beyond hope of recovery, were excluded; but those in which the cankers had not girdled the trunk were divided into two classes-moderately diseased and slightly diseased. Half the trees of each class were fertilized with 2 pounds of ammonium sulfate each. A subsequent irrigation insured incorporation of the fertilizer in the soil.

By midsummer the fertilizer had apparently benefited the trees somewhat: new shoots were produced on unaffected parts of limbs below cankers, and limbs attacked but not girdled by cankers sent out new lateral growth. Many unfertilized trees died entirely or lost most of their limbs. The survivors made poor growth. That the fertilizer did not noticeably affect resistance to subsequent infection was apparent the 
next winter, when fertilized and unfertilized trees were attacked with equal severity.

In two other instances heavy nitrogen applications stimulated moderately diseased plum trees to a vigorous development of new growth from unaffected portions of limbs below cankers and thereby, apparently, enabled some trees and portions of trees to survive the summer.

Fifteen six-year-old President plum trees were fertilized with 2 pounds of ammonium sulfate each in January, 1935. Rains, shortly after the treatment, incorporated the fertilizer in the soil. Late in February, limbs of fertilized trees and of adjacent unfertilized trees were inoculated with the pathogen. Examinations for the next 4 months failed to show any noticeable effect of the fertilizer on rate of cankers developed, although fertilized trees produced somewhat greater shoot growth and greener foliage than unfertilized trees.

The results are tentatively interpreted as follows : An increased nitrogen supply does not enable the tree to resist infection nor to resist markedly the inroads of cankers during spring. It appears beneficial, however, since trees with abundant nitrogen are better able during the summer to recover from effects of the disease than are trees with less nitrogen. One should remember that at this time when the nitrogen is stimulating growth of the tree, the canker activity is waning or is already at its lowest ebb; hence trees that are weakened but not killed at the time the cankers stop growth might survive the summer if temperature and moisture were favorable. Instead, the advent of high temperature and of conditions favoring high transpiration throws a great strain on the trees; common complications then arising are sunburn and attacks by the fruittree bark beetle (Scolytus rugulosus Ratz.). Girdled branches either fail to start growth or else put forth small, yellowish leaves and die during the first hot days of summer. If cankers partly encircle the branch, leaf development may also be slow and sparse (fig. 5). Under cool, spring conditions these branches remain alive and, growing slowly, produce new tissue by which to support the portions distal to the canker. For this reason, apparently, the nitrogen, in stimulating the production of new foliage and new lateral shoots, aids the trees to repair in some measure the damage done by the disease.

Beard and Wormald (1) found no apparent effect of nitrogen on the size of cankers produced by inoculating with Phytomonas mors-prunorum Wor. According to them the largest cankers appeared in trees grown in sand culture and supplied with a "complete nutrient" or a "quadruple phosphate"; the smallest appeared in trees supplied with a nutrient solution lacking in phosphate. 
Effect of Soil Moisture.-Field observations furnished conflicting evidence as to the importance of soil moisture to canker development. In orchards where irrigation practices varied greatly, there were no indications that the disease was affected. Some orchards, for example, were not irrigated after the fruit was picked, so that 2 or more months elapsed between the last irrigation and the first winter rains. Other orchards

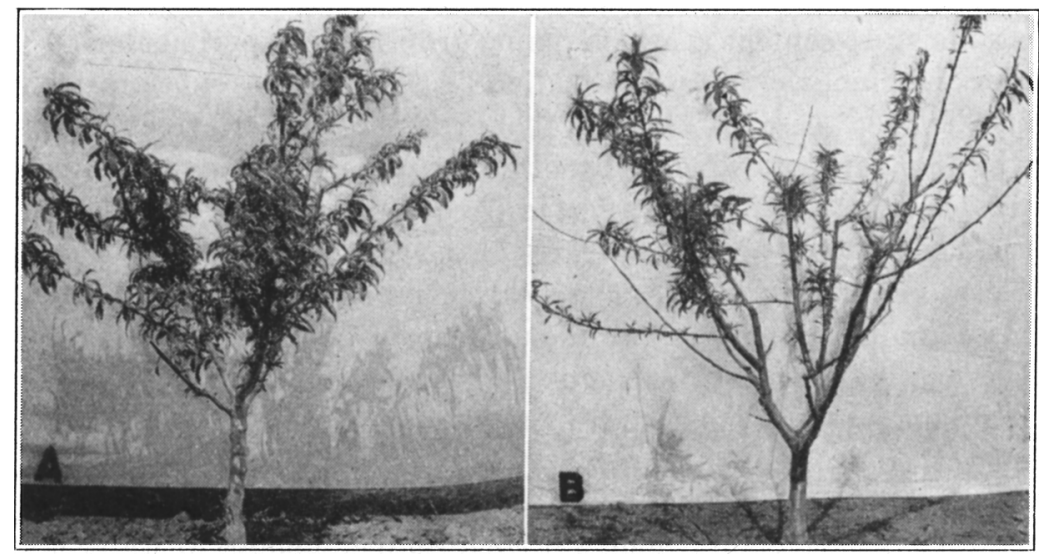

Fig. 5.-Effect of bacterial canker on foliage development in the spring. $A, \mathrm{~A}$ healthy young peach tree. $B, \mathrm{~A}$ peach tree with most of the primary branches diseased, developing small, sparse foliage, some of which has begun to wilt.

were irrigated one or more times after harvest. Two orchards, on the other hand, that had never been irrigated were little affected by the disease, whereas nearby irrigated orchards were badly injured.

Trees in poorly drained areas sometimes appear to suffer worse than those in well-drained areas. In two orchards under observation since 1929 , the disease was at first causing greater damage to the trees in poorly drained areas than to those on well-drained slopes, but later it spread over the entire orchard. In these cases, clearly, infection happened first to become established in the poorly drained areas, but thereafter spread to areas where drainage was good.

Experiments were outlined to study canker development in trees given widely different soil-moisture treatments. Before the experiments are described, however, certain terms used in soil-moisture studies must be defined. Investigators have established two reference points $(13,14)$ with regard to the amount of water in the soil. The first is field capacity, or the capacity of a soil to retain water against gravity. The numerical expression of this value is percentage of water calculated on the basis of oven-dry weight. The second reference point is permanent wilting per- 
centage, or that percentage of moisture in the soil (calculated on an oven-dry basis) below which plants cannot readily obtain water and, in consequence, will permanently wilt unless water is supplied.

Plants can obtain water when the moisture content of the soil is between the field capacity and the permanent wilting percentage. Between these two limits, therefore, is the range of "readily available moisture." There seems to be a widespread belief that somewhere within this range lies a moisture content at which plants grow best. Experiments of Veihmeyer and Hendrickson at this station $(4,5,14)$ do not substantiate this belief. In fact, these workers find that growth of orchard trees and quality of fruit are not affected by differences in the amounts of readily available moisture, but are affected if the soil moisture goes below the permanent wilting percentage early in the growing season.

These investigators $(13,14)$ reveal, moreover, the practical impossibility of maintaining a definite and uniform soil-moisture content within the range between field capacity and permanent wilting percentage. Their papers $(13,14)$ give additional discussion of the principles underlying soil moisture.

Confronting such difficulties, the present writer did not attempt to perform experiments in which a predetermined amount of water added to the soil was assumed to establish a definite and uniform soil-moisture content. Instead the plan was to study the effects of soil moisture on the development of cankers (1) when trees were supplied with readily available moisture at all times and (2) when trees were not so supplied but were growing in soil near or below the permanent wilting percentage. These experiments were conducted on trees growing in the orchard, and on trees growing in tanks ${ }^{5}$ holding about a ton of soil.

Orchard experiments were conducted for three years. In 1934 twoyear-old Duarte and President plum trees were divided into two plots separated from each other by a guard row. In late summer one block was left unirrigated; the other was irrigated at intervals. By early autumn, soil samples taken 3 feet from the base of the trees and to a depth of 6 feet showed that the trees in the unirrigated plot had reduced the soil moisture to a low level. ${ }^{6}$ The irrigated plot was then given a heavy irrigation to a depth of at least 3 feet. The trees in both plots were then inoculated with a water suspension of the pathogen.

The 1934 results, together with the soil-moisture determinations which appear in table 2 , show that only small lesions were developed by the

\footnotetext{
${ }^{5}$ The writer wishes to thank Dr. A. H. Hendrickson and Dr. F. J. Veihmeyer for their aid in planning the experiments and in lending the tanks and equipment.

${ }^{\circ}$ The permanent wilting percentage of the top 4 feet of this soil has been determined by Hendrickson and Veihmeyer to be between 11 and 12 per cent.
} 
inoculations, those on the irrigated trees being slightly smaller than those on the unirrigated. A further difference is noted in the number of inoculations producing cankers : a larger percentage of those on unirrigated trees developed symptoms than did those on irrigated trees. The small differences here reflected are readily explained as follows : Irrigated trees, retaining the ability to produce new tissue around the inoculation wound, promptly buried many small lesions beneath xylem.

TABLE 2

Canker Development in Irrigated and Unirrigated Orchard Trees

\begin{tabular}{|c|c|c|c|c|c|c|c|c|c|c|c|}
\hline \multirow{3}{*}{$\begin{array}{c}\text { Date* } \\
\text { experi- } \\
\text { ment } \\
\text { was } \\
\text { started }\end{array}$} & \multirow{3}{*}{$\begin{array}{l}\text { Variety } \\
\text { of tree } \\
\text { used }\end{array}$} & \multicolumn{5}{|c|}{ Unirrigated trees } & \multicolumn{5}{|c|}{ Irrigated trees } \\
\hline & & \multirow{2}{*}{ 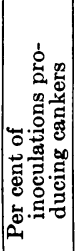 } & \multirow[b]{2}{*}{ 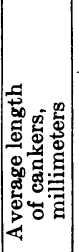 } & \multicolumn{3}{|c|}{$\begin{array}{l}\text { Per cent soil moisture } \\
\text { at depths stated } \dagger\end{array}$} & \multirow{2}{*}{ 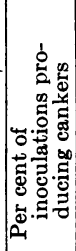 } & \multirow[b]{2}{*}{ 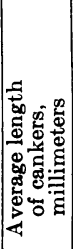 } & \multicolumn{3}{|c|}{$\begin{array}{l}\text { Per cent soil moisture } \\
\text { at depths stated } \dagger\end{array}$} \\
\hline & & & & $\begin{array}{l}0-2 \\
\text { feet }\end{array}$ & $\begin{array}{c}2-4 \\
\text { feet }\end{array}$ & $\begin{array}{r}4-6 \\
\text { feet }\end{array}$ & & & $\begin{array}{c}0-2 \\
\text { feet }\end{array}$ & $\begin{array}{c}2-4 \\
\text { feet }\end{array}$ & $\begin{array}{l}4-6 \\
\text { feet }\end{array}$ \\
\hline Sept. 1934 & Duarte plum & 61 & 15 & 11.5 & 15.2 & 14.7 & 48 & 10 & 22.4 & 22.0 & 17.5 \\
\hline Oct. 1934 & $\begin{array}{l}\text { President } \\
\text { plum...... }\end{array}$ & 90 & 12 & 11.3 & 14.4 & 12.5 & 56 & 7 & 20.9 & 21.9 & 14.1 \\
\hline Oct. 1935 & $\begin{array}{l}\text { President } \\
\text { plum...... }\end{array}$ & 82 & 13 & 10.9 & 13.9 & 12.5 & 61 & 9 & 25.7 & 25.5 & 20.6 \\
\hline Nov. 1936 & Duarte plum & 84 & 25 & 10.8 & 11.8 & 11.4 & 90 & 20 & 24.0 & 22.2 & 18.6 \\
\hline Nov. 1936 & Bing cherry. & 92 & 35 & 10.8 & 11.8 & 11.4 & 87 & 35 & 24.0 & 22.2 & 18.6 \\
\hline
\end{tabular}

* The irrigation and inoculation of trees were made in these months; the cankers were measured 23 to 25 days after inoculation.

$\dagger$ Per cent of moisture based on oven-dry weight of soil.

Since the unirrigated trees, on the other hand, did not possess this ability, a higher percentage of the inoculations produced small cankers. These results, however, reveal no marked tendency for cankers in trees of one treatment to develop further than those in trees of the other treatment. It should be mentioned that, though the moisture in the top 2 feet of soil was at the permanent wilting percentage, the moisture of the soil from 2 to 6 feet in depth was somewhat above that percentage. Hence the trees in the unirrigated plots had a small amount of available moisture at the beginning of the experiment.

Repetitions of this experiment in 1935 and 1936 (table 2) gave no convincing evidence that differences in soil moisture were affecting canker development. The 1936 inoculations produced, in the same length of time, larger cankers than did those of 1934, presumably because they were made later in the autumn. In this year no difference whatever was found between the length of cankers in either the plum or the cherry 
trees receiving the two treatments, though apparently soil moisture to a depth of 6 feet was at the permanent wilting percentage.

In the winter of 1934-35 young Duarte plum trees were planted in tanks holding about a ton of soil. The field capacity and the permanent wilting percentage of this soil had previously been determined. Since the tanks were equipped for weighing, the trees could be given identical treatment with regard to water. So that the roots of the trees might pene-

TABLE 3

Canker Development in Irrigated and Unirrigated Trees

GROWING IN TANKS, 1936-1937

\begin{tabular}{|c|c|c|c|c|c|c|c|c|c|c|c|}
\hline \multirow{2}{*}{ Treatment of trees* } & \multirow{2}{*}{$\begin{array}{c}\text { Date of } \\
\text { inoculation }\end{array}$} & \multicolumn{9}{|c|}{$\begin{array}{c}\text { Average length, } \nmid \text { in millimeters, of cankers produced by } \\
\text { six inoculations in each tree }\end{array}$} & \multirow{2}{*}{$\begin{array}{l}\text { Aver- } \\
\text { age }\end{array}$} \\
\hline & & $1 \ddagger$ & 2 & 3 & 4 & 5 & 6 & 7 & 8 & 9 & \\
\hline Irrigated. & Oct. $\quad 15,1936$ & 14 & 14 & 14 & 18 & 10 & 11 & 18 & 16 & 18 & 15 \\
\hline Unirrigated. & Oct. 15,1936 & 0 & 1 & 1 & 2 & 5 & 7 & 10 & 0 & 1 & 3 \\
\hline Irrigated $\ldots \ldots \ldots \ldots$ & Oct. $\quad 24,1936$ & 34 & 20 & 30 & 39 & 27 & . & . & . & . & 30 \\
\hline Unirrigated . . . . . . . & Oct. 24,1936 & 0 & 1 & 0 & 3 & 4 & .. & .. & . & . & 2 \\
\hline Unirrigated-irrigated & Oct. 24,1936 & 15 & 7 & 10 & 10 & . & . & . & . & . & 13 \\
\hline Irrigated $\ldots \ldots \ldots \ldots$ & Oct. $\quad 31,1936$ & 21 & 19 & 24 & 9 & 20 & . & . & . & . & 19 \\
\hline Unirrigated. & Oct. 31,1936 & 3 & 4 & 8 & 1 & 2 & .. & . & . & . & 4 \\
\hline Irrigated... & June $\quad 5,1937$ & 33 & 24 & 21 & 29 & 37 & .. & .. & . & .. & 29 \\
\hline Unirrigated. & June $\quad 5,1937$ & 4 & 0 & 0 & 2 & 1 & .. & $\because$ & . & $\ldots$ & 1 \\
\hline
\end{tabular}

* Irrigated-soil moisture kept above the wilting point at all times.

Unirrigated-soil moisture brought to the wilting point and kept there during the experiment.

Unirrigated-irrigated-soil moisture at the wilting point until inoculations were made, then brought to field capacity for the duration of the experiment.

+ Measurements made 10 days after inoculation.

$\ddagger$ Numbers 1 to 9 designate the different trees that were inoculated.

trate all the soil in the tanks, the differential moisture treatments were not begun until early autumn, 1936. In late summer of that year half of the tanks were left unwatered. The other half were maintained considerably above the permanent wilting percentage at all times. By midOctober, weighings indicated that the unwatered trees had reduced the soil moisture to the permanent wilting percentage. Additional evidence that this point had been reached was furnished by the trees themselves, in that the leaves wilted and fell. The soil in the irrigated tanks was again brought to its field capacity and was kept wet for the duration of the experiment. Six inoculations were made into each tree on three different dates. The first series was made October 15, the second October 24, and the third October 31. On October 24 four trees that had been allowed to wilt were irrigated when they were inoculated.

As shown by the results in table 3 , trees of the two treatments differed strikingly in canker development. According to measurements 10 days after inoculations, whereas the bacteria were producing fairly large 
cankers in irrigated trees, there was little evidence of canker development in the wilted trees. In June, 1937, this experiment was repeated on 10 of these trees with similar results. When trees previously wilted were irrigated at the time of inoculation, the bacteria proceeded to produce distinct cankers-less extensive, however, than those in continuously irrigated trees.

At first examination it seems impossible to reconcile the divergent results of the two types of experiments. Since, however, results of the tank experiments were so definite, the divergence must have been caused by the dissimilar conditions under which the experiments were conducted. As mentioned earlier regarding the 1934 orchard experiments, trees in the dry plot apparently had a small amount of available moisture at the beginning of the experiment. The same is true of the 1935 experiments. In 1936, on the other hand, the soil in the dry plots was at the permanent wilting percentage to a depth of 6 feet. Since, however, this condition was not reached until late autumn, when trees in both wet and dry plots were losing their leaves, no actual wilting of foliage was observed. Possibly, though most of the roots of these trees were in soil where moisture was at the permanent wilting percentage, a few might have been in moist soil below the 6 -foot depth. In this connection Conrad and Veihmeyer (3) conclude from their work with sorghum that "if a portion of the root system is partly in dry soil and partly in wet soil, the needs of the plants might be adequately met by adsorption from moist soil."

Apparently, therefore, under conditions in orchard experiments, where most of the roots were in dry soil but where a few roots might have been supplying the trees with moisture, no effect on canker development was exerted. As mentioned earlier, the small differences indicated in the 1934 results can be explained as arising through differences between the ability of the trees in wet and dry plots to bury diseased areas beneath new host tissue. The differential of soil moisture in the field experiments did not appear to make trees strikingly more or less susceptible.

So much for differences occurring in the orchard tests only. The differential in soil moisture obtained in the tank experiments was unquestionably greater. Not only was this found by weighing the tanks, but the trees themselves gave evidence, in that leaves of trees in wet tanks remained turgid, whereas those of trees in the dry tanks wilted and dropped. Unquestionably, therefore, the soil moisture in the dry tanks was below the permanent wilting percentage. The consistency with which cankers failed to develop in the dry trees appears to be adequate proof that lack of readily available soil moisture affected the disease under the extreme conditions obtaining. 
Whether the extreme conditions of the tank experiments would occur under orchard conditions, where the tree roots are not restricted to a limited mass of soil, depends upon the depth of the soil, the range of readily available moisture, the characteristics of the soil, and the proximity of a water table to the surface. Trees in the Sierra Nevada foothills, where the soil is shallow and where the range of readily available moisture is narrow, are more liable to suffer extreme drought conditions in absence of irrigation than trees growing in the Sacramento Valley. The unirrigated orchards mentioned at the beginning of this discussion were located in the foothill district and exhibited definite drought symptoms during late summer. The leaves dropped early, and the trees were obviously stunted. This might have been one reason why the disease damaged unirrigated trees very little but caused severe damage in nearby irrigated orchards.

Just how drought effect, coming in later summer when canker activity is at a low ebb, could influence the severity of the disease, is not known. The most likely influence would seem to be on survival of bacteria in the cankers, which would in turn affect the supply of inoculum the following winter. Though this problem was not extensively studied, observations in one winter indicated an apparent difference between an irrigated and an unirrigated orchard in the percentage of active cankers. In the unirrigated orchard, 28 per cent of the cankers were active; in an adjacent irrigated orchard, 71 per cent. Obviously these results are too meager to permit conclusions.

\section{RELATION OF VARIETY OF PLUM TO DISEASE DEVELOPMENT}

The behavior of different varieties of plums towards the disease appeared to deserve further study. Since earlier work (16) had revealed a marked variability in the reaction of several commonly grown varieties to the presence of cankers in the limbs, it was thought that by observing a few of these varieties, some apparently resistant and others susceptible, one might learn whether or not any common characteristic of behavior existed. Before these studies are discussed, information regarding resistance and susceptibility, other than that already published (16), must be given.

Whatever the basis for classifying varieties according to resistance and susceptibility, whether it be the number of trees partially or wholly killed, or the frequency with which the trees are attacked, the result is a composite, the integral parts of which exist for different reasons. If, for example, the basis is tree mortality, one variety may suffer little loss, 
perhaps because the trees are inherently resistant to attack or because they are, when attacked, not favorable to rapid extension of canker, or because they somehow escape infection. If, on the other hand, the basis is the frequency with which the disease occurs in trees of the different varieties and if no attention is paid to the number of trees wholly or partially killed, the results will reflect any existing inherent resistance to attack and any escape ; but they will not necessarily show how favorable or unfavorable the trees of particular varieties are to extension of cankers once infection is established.

These points are stressed because one can interpret the following data best by keeping in mind the factors contributing to those phenomena called susceptibility and resistance. No claims are made that the data to be given reflect, or could have been made to reflect, the separate influences of the contributory factors. In some outstanding examples to be cited, the severity of the disease in a given variety in a given year was almost certainly conditioned by one or more of these factors.

Susceptibility from the Standpoint of Frequency of Infection.-That differences in incidence of infection may in some years be among the important causes of heavier losses in one variety than in other equally susceptible varieties was recently observed. In 1935 Duarte trees in certain orchards were wholly or partially killed in greater numbers than adjacently growing President, Grand Duke, or Tragedy, mainly because they became infected through blossom buds and apparently, in some cases, through the open blossom itself or through the bases of the blossoms. In 1936 the reverse was true; President trees suffered more from blossom bud infection than did Duarte. In 1937 Duarte, Wickson, and Santa Rosa trees were, on the whole, attacked through buds far more frequently than President, Grand Duke, or Tragedy. From the standpoint of the rapidity of canker extension, once infection is established, President seems somewhat more susceptible than Duarte.

Susceptibility of Different Varieties from the Standpoint of Tree Mortality.-The 1933 classification of the susceptibility of plum varieties was based on records of the percentage of trees wholly or partially killed during the 1930 outbreak. Additional observations considerably alter this list, particularly on varieties falling between the two extremes of susceptibility. Climax, for example, listed as more susceptible than Grand Duke and Tragedy, seemed in later years considerably less affected than they. One should not infer, however, that in all years the three varieties differ widely with respect to the number of trees lost. One reason for the seeming change from one year to another, of comparative susceptibility between different varieties was given under the preceding heading. 
A further change in order of susceptibility concerns the Sugar variety, which is undoubtedly more susceptible than indicated by its position in the list (16).

Regarding the most susceptible and most resistant varieties the list needs little revision: President and Duarte have consistently suffered greater loss than any others; Kelsey and Beauty, very little loss.

Table 4 shows the wide difference of susceptibility between a few important varieties. To minimize differences arising from the existence of

TABLE 4

Susceptibility of Different Varieties of Plums to Bacterial Canker

\begin{tabular}{|c|c|c|c|}
\hline $\begin{array}{l}\text { Year } \\
\text { observa- } \\
\text { tions were } \\
\text { made }\end{array}$ & $\begin{array}{l}\text { Orchard } \\
\text { number }\end{array}$ & Variety of plum* & $\begin{array}{l}\text { Per cent of trees } \\
\text { badly diseased } \dagger\end{array}$ \\
\hline 1933 & 1 & 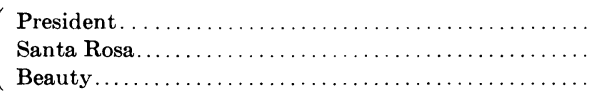 & $\begin{array}{l}41 \\
16 \\
12\end{array}$ \\
\hline 1933 & 2 & 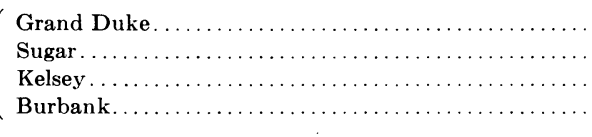 & $\begin{array}{r}70 \\
58 \\
5 \\
12\end{array}$ \\
\hline 1934 & 3 & 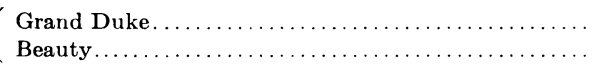 & $\begin{array}{l}25 \\
11\end{array}$ \\
\hline 1937 & 4 & 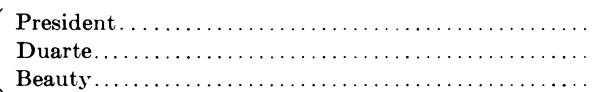 & $\begin{array}{r}27 \\
13 \\
0\end{array}$ \\
\hline
\end{tabular}

* President, Grand Duke, and Sugar are Prunus domestica varieties; Santa Rosa, Beauty, Kelsey, and Burbank, $P$. salicina varieties; Duarte appears to be a $P$. salicina hybrid.

+ This includes trees in which the disease was severe enough to kill branches or the entire tree.

localized infection centers that might have become established in one block of trees and not in another, observations in a given orchard were confined to adjacently growing trees of the same age. These data show the consistently high susceptibility of President, Grand Duke, and Sugar in contrast to the resistance of such varieties as Beauty and Kelsey. Burbank and Santa Rosa appear intermediate. Duarte trees (observations of 1937) were affected much more than Beauty but not so badly as President when the Duarte trees were adjacent to the other two varieties. This difference should be remembered during later discussion.

Differences in the Rate of Canker Extension in Varieties of Plums.The comparative susceptibility of President and Duarte plum has been approached from the standpoint of the rate at which cankers extend in the limbs of each. At various times during 1935, 1936, and 1937 adjacently growing trees of the two varieties were inoculated. The trees were 


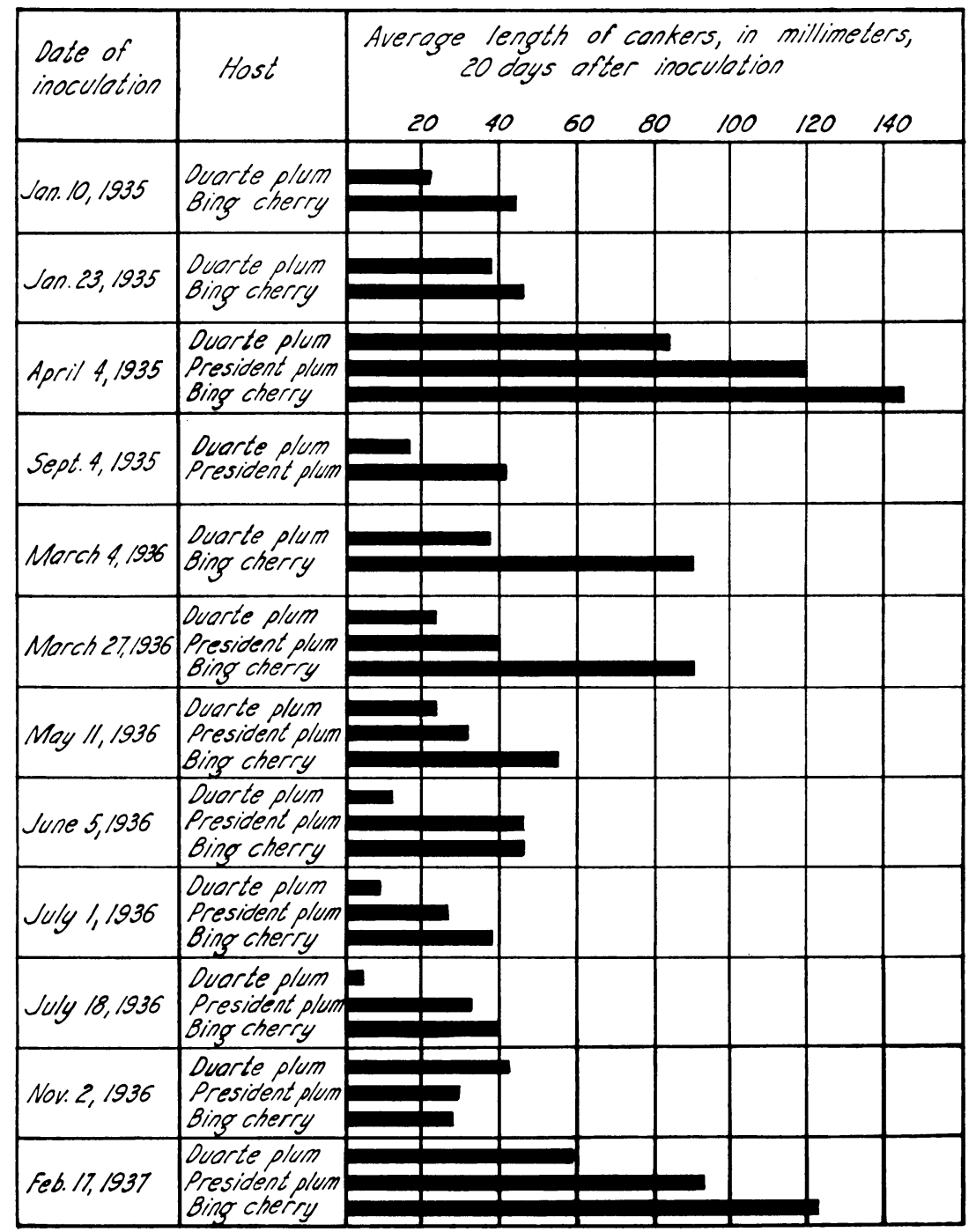

Fig. 6.-Canker development in two varieties of plums and one variety of sweet cherry. The data indicate that Duarte plum trees are somewhat less favorable to extension of cankers than President plum and Bing cherry trees.

of the same age, having been planted in the winter of 1931-32. For comparison Bing cherry trees of the same age were also inoculated. Cankers were measured 20 days after inoculation.

According to figure 6 larger cankers were produced in limbs of the variety President than in Duarte, with but one exception. As might be 
expected from the inoculation results given earlier in this paper, cankers produced at different times of the year varied in size. This was true of both plums and the cherry as well. With but two exceptions, cankers produced in the cherry limbs were somewhat larger than those produced in President.

Here we see further evidence for regarding Duarte as less susceptible than President, even though in some years more Duarte than President trees were wholly or partially killed. This work raises the question as to whether or not other varieties of plums differ with respect to the comparative rate of canker extension after infection occurs. Though no comparable body of data is available on the point, one series of inoculations made January 12, 1938, in Placer County leads one to believe that other varieties do differ in respect to the rate of canker development. The average length of canker, 44 days after inoculation, for several varieties of plums is tabulated as follows:

\begin{tabular}{|c|c|}
\hline \multirow{2}{*}{\multicolumn{2}{|c|}{$\begin{array}{c}\text { Variety } \\
\text { President }\end{array}$}} \\
\hline & \\
\hline Grand Duke. & $\ldots 64$ \\
\hline Sugar ...... & $\ldots 57$ \\
\hline Duarte & 45 \\
\hline Burbank. & $\ldots 45$ \\
\hline Beauty & .. 19 \\
\hline Kelsey & $\ldots 12$ \\
\hline
\end{tabular}

According to these data, the European type of plum (President, Grand Duke, and Sugar) developed larger cankers than the Japanese type (Duarte, Burbank, Beauty, and Kelsey). In the previous section, the Beauty, Kelsey, and Burbank varieties were said to suffer less loss of trees than such varieties as President, Grand Duke, and Sugar. The inoculation results indicate a possible reason for the difference in susceptibility, in that cankers in Kelsey and Beauty developed less rapidly than those in President, Grand Duke, and Sugar.

\section{INTERNAL REACTIONS OF THE HOST IN RELATION TO CANKER DEVELOPMENT}

We shall now consider the morphological changes in the host tissue that might be construed as reactions to the bacteria and shall attempt to determine whether such changes affect canker activity.

Nature of the Reactions. - Strictly speaking, reactions to the bacteria are of two types: (1) those in which the vascular cambium, or at least undifferentiated cells in that region, are concerned; and (2) those in which a cork cambium or phellogen is concerned. Both these types of reactions may occur in different parts of the same canker. 
Frequently the margins of cankers advance only along a restricted zone in the vascular cambium. The bacteria may later invade the overlying phloem and cortical tissue ; but often diseased areas in the cambial region at the margins of the cankers will be buried beneath new tissue generated by unaffected cambial cells-or at least by undifferentiated cells in the cambial region-before the bacteria have time to invade the phloem and cortex. This new tissue, interestingly enough, is xylem laid down in a more or less regular fashion. As shown in figure 7, the new developing

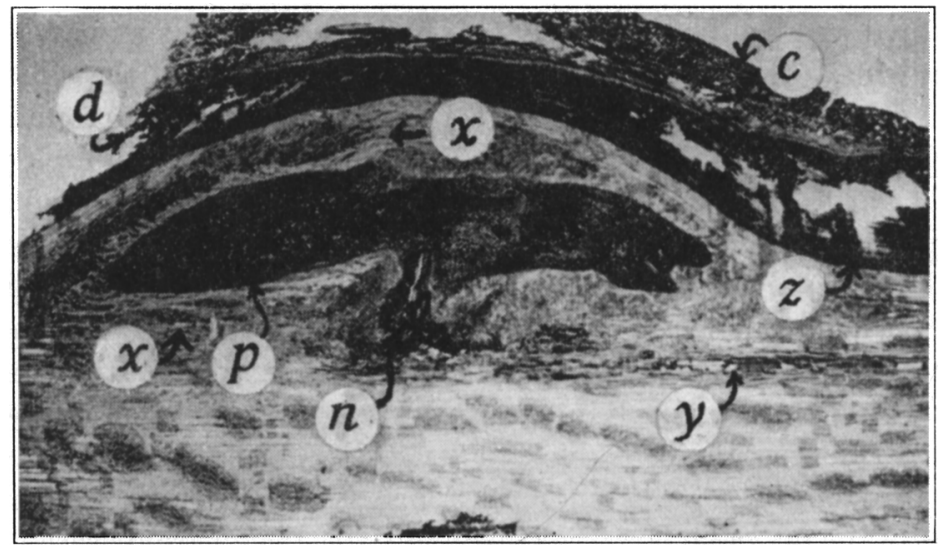

Fig. 7.-Radial longitudinal section through the bark of a Duarte plum branch inoculated on September 15, 1935, fixed two months later, showing how part of the diseased phloem tissue $(p)$ is buried by laterformed xylem $(x)$. Infected phloem tissue $(d)$ has been separated by means of a phellogen from remaining healthy phloem and cortex (c). At $y$ the disease has extended along what were then outer layers of sapwood, buried by new xylem $(x)$ through activity of the cambium $(z)$. Apparently the only derivative of this cambium is xylem. The path of the needle is shown at $n$ and in the immediate neighborhood some of the tissue has become infected; this diseased tissue extends along $y$.

xylem may, in needle-prick inoculations, occlude some phloem tissue at the point of inoculation. Since the host responds similarly, but less extensively, near wounds made with a sterile needle, we cannot attribute the response evident around the needle wound in figure 7 as stimulated wholly by bacteria. The bacteria have, however, invaded $(d)$ above and below the path of the needle $(n)$. When the invasion occurred the lowermost area of diseased tissue was in the cambial region but was subsequently buried beneath new xylem $(x)$. This type of host reaction departs but little from the normal production of new tissue by the cambium. The bacteria had invaded considerable phloem $(d)$, but when the fixation was made this infected area was separated from the overlying healthy 
phloem and cortex (c) by a periderm. The response involved the production of a phellogen, which will be considered next.

A phellogen develops at the lateral margins of a canker and generates a mass of new tissue similar in some respects to that developing at wounds. If the bacteria have invaded the bark tissue downward to the cambium both at the apices and the lateral margins of the canker, the mass of new tissue may extend entirely around the infected area. More frequently, however, such tissues are formed only along the lateral margins; the apical margins will be seen to diffuse into a series of loosely connected reddish-brown streaks, forming a zone sometimes several inches wide. Microscopic examination of cross sections of these reddishbrown dormant streaks will show a core of infected tissue surrounded by a periderm sometimes 10 to 15 cells thick. The cross-section area of the streaks varies from only a few cells to many hundred, the number depending on the amount of tissue invaded when the periderm was formed. The thickness of the periderm varies among different diseased areas. Extremely vigorous periderm formation sometimes occurs when the cankers are located in the outer layers of the bark ; the inner face of the canker is separated from the underlying healthy tissue by a phellogen that generates a periderm many cells thick. When exposed the periderm cells may separate from each other and fall apart as a powdery mass; and by breaking the outer layer of bark one may lift the entire diseased, dead area away from the underlying healthy tissue. A somewhat similar situation exists in the pear-blast canker caused by the same organism $(17,18)$.

Although not studied in detail, the major anatomical changes occurring when phellogen appears around infected streaks at the apices of cankers have been noted. The first noticeable sign of phellogen formation was an apparent clearing of a zone of healthy cells at the periphery of infected streaks. The cause of this clearing, noticeable in freehand sections of fresh material, was not determined. Priestley (8), noticing a similar clear zone, attributed it to the absence of air between the cells. A translucent, watery appearance of cells near the vascular cambium just before cambial activity in the spring was said by Priestley (8) and by Priestley and Swingle (9) probably to mean that the cell contents had changed from a condition of a gel to one of a sol. In the present work the clearing first occurred in cells on the face of the diseased area nearest the vascular cambium. Shortly thereafter certain cells in the cleared zone laid down walls parallel to the margin of the diseased area. New cells were then generated by this layer. Figure 8 shows three stages: $(A) \mathrm{A}$ cross section through diseased bark before the phellogen appears. Since, in this case, the bacteria did not involve all the cells near the invasion, 


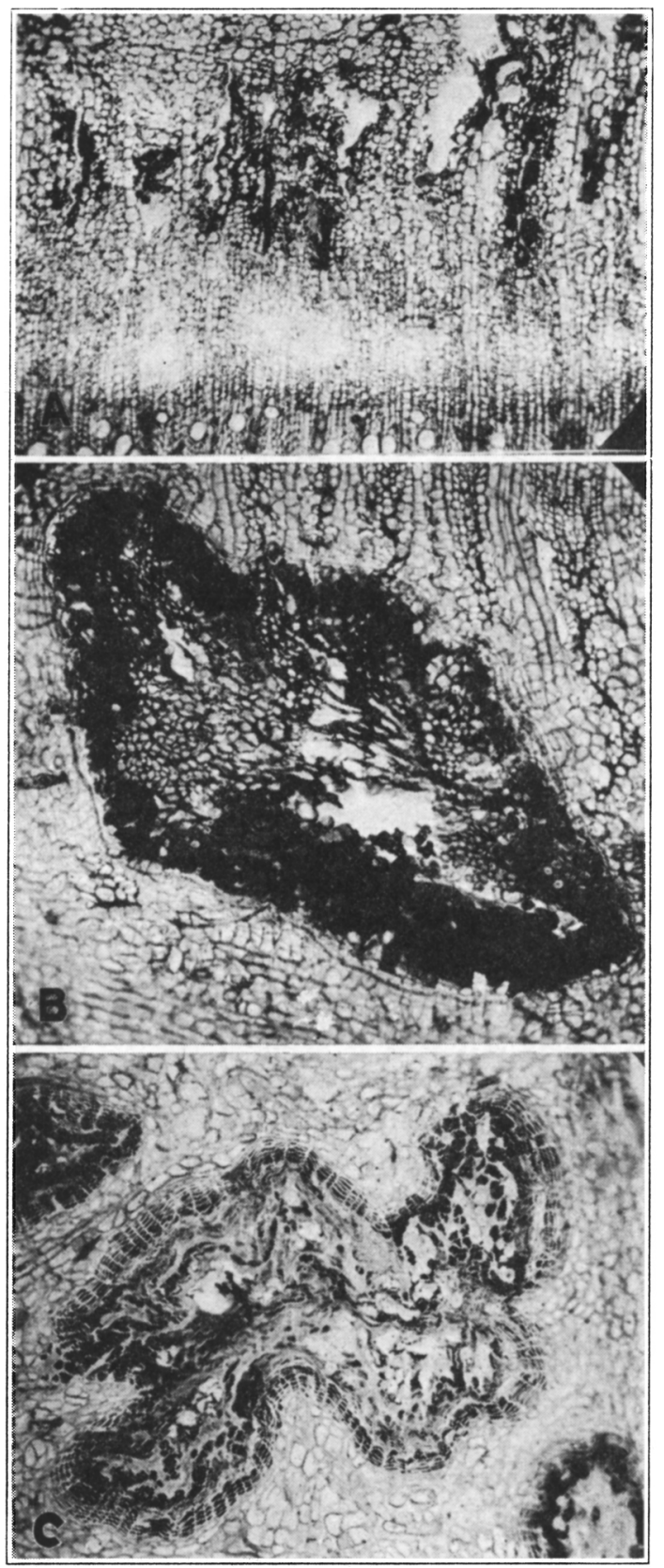

Fig. 8.-Cross sections through diseased bark of plum in different stages of phellogen development. $A$, Before phellogen has formed; note the indefinite, diffused region of invaded tissue. $B$, Well-defined, gum-impregnated invaded region after a phellogen has formed. $C, \mathrm{~A}$ well-developed periderm separating infected from healthy tissue. 
the limits of the diseased area are ill-defined. (B) A cross section through a diseased area around which phellogen has formed and has begun to produce new cells. The diseased region is now well defined, and most of the cells in the region are involved. $(C)$ A cross section through a diseased region surrounded by periderm 6 to 7 cells thick.

Relation of Host Activity to Periderm Formation.-From the work of others (8) we know that cambial activity, initiated at the base of the bud when the buds begin to grow, spreads to all parts of the tree. Bud growth

TABLE 5

Development of Periderm Around Invaded Areas in the Bark of aN Early and a Late Blooming Varietr of Plum, 1935

\begin{tabular}{|c|c|c|c|c|c|}
\hline \multirow{2}{*}{\multicolumn{2}{|c|}{$\begin{array}{l}\text { Date of } \\
\text { fixation }\end{array}$}} & \multicolumn{2}{|c|}{ Duarte (early blooming) } & \multicolumn{2}{|c|}{ President (late blooming) } \\
\hline & & $\begin{array}{l}\text { Stage of host } \\
\text { development }\end{array}$ & $\begin{array}{l}\text { Occurrence of } \\
\text { phellogen }\end{array}$ & $\begin{array}{l}\text { Stage of host } \\
\text { development }\end{array}$ & $\begin{array}{l}\text { Occurrence } \\
\text { of phellogen }\end{array}$ \\
\hline Feb. & 21 & Closed cluster & None & Dormant & None \\
\hline Feb. & 27 & $\begin{array}{l}\text { Open cluster, tips of two leaves } \\
\text { exposed }\end{array}$ & None & Buds swelling & None \\
\hline Mar. & 12 & $\begin{array}{l}\text { Full bloom, two leaves un- } \\
\text { folded }\end{array}$ & Beginning & Closed cluster & None \\
\hline April & 4 & $\begin{array}{l}\text { Ten leaves unfolded, largest } \\
53 \times 18 \mathrm{~mm}\end{array}$ & Well developed & $\begin{array}{l}\text { Just past full bloom, three } \\
\text { leaves unfolded, largest } 20 \\
\times 10 \mathrm{~mm}\end{array}$ & Beginning \\
\hline
\end{tabular}

is, therefore, a visible criterion of cambial activity; those varieties of plums that blossom earliest will start cambial activity earliest. As far as the reaction of the tree to the presence of Phytomonas cerasi, as just outlined, concerns the activity of vascular cambium at the margins of invaded and healthy tissue, those varieties which bloom earliest will presumably be the earliest to produce new tissue in such areas. But, since reaction of the host to the presence of the bacteria also involves periderm formation in phloem and cortical tissue, it was necessary to study the relation between this phenomenon and growth of the tree.

To define the connection between the beginning of growth of the host in the spring and periderm formation around diseased areas in phloem and cortex, the following studies were made. Limbs of Duarte plum trees were inoculated in early February, 1935. At 3- to 4-day intervals, pieces of tissue at the apices of the developing cankers were examined for phellogen. As long as the trees remained dormant no phellogen was produced, but when the buds started growth a phellogen appeared and began to generate periderm. In these particular cases about three weeks elapsed 
between inoculation and the first observed phellogen. The time necessary for phellogen development after inoculations in late May was, on the other hand, between 9 and 11 days.

Thus it seems that periderm formation around invaded areas in phloem and cortex appears also to be determined by activity of the tree. Between late autumn and early spring or, in other words, during dormancy of the trees, it was not observable.

Periderm Formation around Diseased Areas in Different Varieties of Plums.-Since periderm formation around invaded areas begins in the

TABLE 6

Relation of Varieties of Plums to Certain Characteristics of THE CANKers DURING THE SUMMER OF 1932

\begin{tabular}{|c|c|c|}
\hline Variety* & Species & $\begin{array}{c}\text { Per cent of } \\
\text { cankers with } \\
\text { reddish-brown } \\
\text { streaks at } \\
\text { margins of } \\
\text { necrotic area }\end{array}$ \\
\hline Clyman & Prunus domestica.. & 15 \\
\hline Sugar & P. domestica.... & 5 \\
\hline Grand Duke & P. domestica.. & 18 \\
\hline Tragedy & P. domestica... & 28 \\
\hline California Blue & P. domestica....... & 26 \\
\hline Duarte & P. salicina $\dagger . . . . \ldots \ldots$ & 58 \\
\hline Santa Rosa & $P$. salicina . . . . . . . . . . . & 73 \\
\hline Wickson & 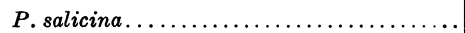 & 78 \\
\hline
\end{tabular}

* Santa Rosa, Duarte, and Wickson varieties blossom much earlier in the spring than do the other varieties.

$\dagger$ Duarte appears to be a Prunus salicina hybrid.

spring only after the trees start growth, it should differ in varieties that started growth at different times. Two varieties of plums, one of which (Duarte) begins growth 2 to 3 weeks earlier than the other (President), were inoculated February 10, 1935. Freehand sections of the cankers at different times after inoculation showed that the Duarte began to form a periderm around infected tissues about 3 weeks before the President (table 5). The first observed periderm appeared in both varieties at about the same stage of their development-that is, just before full bloom.

No similar body of data is at hand regarding development of a periderm in other varieties. Such studies would be valuable, particularly in the varieties Beauty and Kelsey, which besides starting growth early are much more resistant to the disease than Duarte. Judging from some observational data, however, Kelsey and Beauty tend to produce periderm earlier in the spring than such varieties as President, Grand Duke, and Tragedy. Early in the work the characteristics of cankers during the 
summer were found to differ among varieties. At first no particular importance was attributed to this fact, but later evidence showed that these differences were caused by the presence or absence, and by the relative amount, of periderm around infected streaks at the apices of cankers. Cankers, for example, could be separated on the following bases: (1) those in which the dull-brown, watery margins gradually merged into

\section{TABLE 7}

Comparison of the Varieties of Plums with Respect to Certain Characteristics of the Cankers During

MAY, 1935, AND MAY, 1937

\begin{tabular}{|c|c|c|c|c|c|}
\hline $\begin{array}{c}\text { Date of } \\
\text { observation }\end{array}$ & Variety* & Species & Class $1 \dagger$ & Class $2 \ddagger$ & Class 39 \\
\hline \multirow{6}{*}{ May 29,1935} & President & Prunus domestica. . & 58 & 26 & 16 \\
\hline & Grand Duke & $P$. domestica.......... & 32 & 33 & 35 \\
\hline & Tragedy & P. domestica.... & 40 & 40 & 20 \\
\hline & Duarte & P. salicina... & 18 & 38 & 44 \\
\hline & Beauty & P. salicina. & 6 & 17 & 77 \\
\hline & Santa Rosa & P. salicina.. & 0 & 1 & 99 \\
\hline \multirow{5}{*}{ May 19,1937} & President & P. domestica. & 66 & 34 & $\mathbf{0}$ \\
\hline & Grand Duke & P. domestica.. & 53 & 47 & 0 \\
\hline & Tragedy & P. domestica. & 31 & 54 & 15 \\
\hline & Duarte & P. salicina... & 6 & 56 & 38 \\
\hline & Beauty & P. salicina... & 0 & 39 & 61 \\
\hline
\end{tabular}

* The order in which these varieties blossom in the spring is: Santa Rosa, Beauty, Duarte, Tragedy, Grand Duke, President-the Santa Rosa being earliest and the President latest.

$\dagger$ Class 1, cankers with few or no dormant streaks.

$\ddagger$ Class 2, cankers with a considerable number of dormant streaks.

Class 3, cankers with most of the visibly invaded tissue in the form of dormant streaks.

healthy tissue, with no reddish-brown dormant streaks, and (2) those in which the margins were well defined at the edges of the necrosed area and which also possessed a zone of the reddish-brown dormant streaks beyond the necrosed area. Data in table 6 collected during the summer of 1932 reveal a striking difference between varieties in the percentage of cankers belonging to the second type. Trees of Prunus domestica varieties bore markedly fewer cankers of this type than did those of P. salicina varieties.

In May, 1935, and May, 1937, further evidence on this point was obtained. Based upon the character of the canker with respect to the presence or absence and the relative abundance of dormant streaks, three classes of cankers were obtained : (1) cankers having very few or no dormant streaks at the apices, (2) cankers having a considerable number of dormant streaks intermingling with the dull-brown, active streaks, and (3) cankers having most or all of the visibly infected tissue at the apices in the form of the reddish-brown dormant streaks. Only such cankers 
as had enlarged during the previous winter and spring were included. Those that had girdled the limb were omitted, since presumably such weakened limbs would not react to the presence of the disease with the same vigor as ungirdled limbs. According to data presented in table 7 the Prunus domestica varieties again separated themselves from the $P$. salicina with regard to the abundance of infected streaks surrounded by periderm. In this respect Duarte stood intermediate between President on the one hand and Beauty on the other. Apparently, therefore, the early varieties are first to start periderm formation.

Callus Formation at the Surface of Mechanical Wounds in Different Varieties of Plums.-Response of different varieties of plums to wounds inflicted during dormancy was observed for two seasons. Although the response to surface wounds might differ in certain details from that occurring at the margins of diseased areas in the interior of the bark, the presumption was that the wound response, in regard to its vigor and to the time it began in the spring, would coincide with the response at the margins of invaded areas.

Trees of about the same age and growing in nearby plantings given the same cultural treatments were used in these studies. Early in February 1-inch holes were bored into 5 limbs of each of 5 trees of the different varieties. The holes, extending through the cambial region to the sap wood, were painted with shellac in accordance with the work of Marshall (6), who found that shellacking aided callusing in forest and shade trees. At different times thereafter the wounds were observed for callus, which first developed as a light-green, cheesy mass of tissue at the lateral sides of the holes. The length and width (at the widest point) of these callus masses were measured at two different times. The measurements of length were multiplied by the measurements of the width to obtain a callusing index. These indices, together with information concerning stage of development of the different varieties at the time the callus was measured, appear in table 8 .

In 1934 the experiment included three varieties : President, one of the latest plums to start growth ; Beauty, moderately early ; and Santa Rosa, very early. By March 9, according to the data in table 8, Beauty and Santa Rosa, but not President, had developed a measurable amount of callus. By March 22, President had developed considerable callus, but the other two varieties were far ahead, Santa Rosa more so than Beauty.

The 1935 experiments included seven varieties that differed both in their susceptibility to the disease and in their earliness to start growth. In addition younger trees (nine years old) of two of the varieties were studied. Callusing began when the blossom buds were opening (table 8 ). 
The first to begin were the earliest-blooming varieties, Santa Rosa being the earliest. There was a great difference between Prunus domestica varieties (President, Grand Duke, and Tragedy) and those of $P$. salicina (Kelsey, Beauty, Santa Rosa, and Duarte); the latter group began to form callus earlier than the former. In addition the young Beauty trees were somewhat later to bloom and later to begin callusing than the older Beauty. This, however, was not the case with young President.

TABLE 8

Callusing of Wounds in Difrerent Varimties of Plums

\begin{tabular}{|c|c|c|c|c|c|c|c|}
\hline \multirow[b]{2}{*}{ Year } & \multirow[b]{2}{*}{ Variety } & \multicolumn{3}{|c|}{ First observation* } & \multicolumn{3}{|c|}{ Second observation } \\
\hline & & $\underset{\text { development }}{\text { Host }}$ & $\begin{array}{c}\text { Per } \\
\text { cent } \\
\text { of holes } \\
\text { callus- } \\
\text { ing }\end{array}$ & $\begin{array}{l}\text { Callus- } \\
\text { ing } \\
\text { index } \ddagger\end{array}$ & Host development $\dagger$ & $\begin{array}{c}\text { Per } \\
\text { cent } \\
\text { of holes } \\
\text { callus- } \\
\text { ing }\end{array}$ & $\begin{array}{l}\text { Callus- } \\
\text { ing } \\
\text { index } f\end{array}$ \\
\hline \multirow{3}{*}{1934} & Santa Rosa & End of bloom & 80 & 16 & Fruit 4-5 $\mathrm{mm}$ diameter & 100 & 99 \\
\hline & Beauty & Full bloom & 64 & 10 & Fruit 3-4 mm diameter & 96 & 40 \\
\hline & President & Dormant & 0 & 0 & 10 per cent blossoms open & 60 & 13 \\
\hline \multirow{10}{*}{1935} & Santa Rosa & Open cluster & 54 & 5 & 5 leaves unfolded & 100 & 38 \\
\hline & Kelsey & $\begin{array}{l}\text { Early open } \\
\text { cluster }\end{array}$ & 44 & 4 & 7 leaves unfolded & 96 & 24 \\
\hline & Duarte & Early open & & & & & \\
\hline & & cluster & 44 & 4 & 4 leaves unfolded & 100 & 32 \\
\hline & Beauty & $\begin{array}{l}\text { Early open } \\
\text { cluster }\end{array}$ & 60 & 6 & 1 leaf unfolded & 93 & 23 \\
\hline & $\begin{array}{l}\text { Beauty (young } \\
\text { trees) }\end{array}$ & Buds swelling & 28 & 3 & Full bloom & 68 & 8 \\
\hline & Tragedy & Buds swelling & 0 & 0 & 50 per cent blossoms open & 74 & 9 \\
\hline & Grand Duke & Dormant & 0 & 0 & 15 per cent blossoms open & 48 & 4 \\
\hline & President & Dormant & $\mathbf{0}$ & $\mathbf{0}$ & Open cluster & 40 & 2 \\
\hline & $\begin{array}{l}\text { President } \\
\quad \text { (young trees) }\end{array}$ & Dormant & 0 & 0 & Open cluster & 70 & 3 \\
\hline
\end{tabular}

* First observation in 1934 was March 9, and in 1935, February 18; second observation in 1934 was March 22, and in 1935, March 19.

$\dagger$ Although most designations of the stages of host development are self explanatory, the following are defined: "buds swelling" and "buds breaking" refer to the enlargement and separation of the scales of the buds containing blossoms; "early open cluster" and "open cluster" indicate different stages in the separation of individual blossoms in clusters after they have emerged from the bud scales.

$\ddagger$ Index number derived by multiplying length of callus tissue by its width.

\section{Relation of Host Development and Periderm Formation to Canker} Development.-Three different methods of approach indicated in the foregoing section that those varieties first to start growth in spring were also first to produce periderm around diseased areas or callus at the surface of wounds. If we now compare these data (tables $5,6,7$ ) with those (table 4) concerning susceptibility of varieties we find, on the whole, that the varieties first to start growth (Kelsey, Beauty, and Santa Rosa) were among the more resistant, while those starting growth later (President, 
Grand Duke, and Tragedy) were the more susceptible. An apparent exception was Duarte, which, though highly susceptible to infection through buds, appeared less favorable to extension of cankers than President. In other words, these two varieties differ with regard to the rate of canker development once infection is established, cankers in President extending more rapidly than those in Duarte. Periderm formation, moreover, starts earlier in Duarte than in President (tables 5 and 8). Hence the above generalization apparently holds true for all varieties tested.

The inference from this discussion is that periderm may possibly play a part in limiting canker activity. Earlier work (16) had suggested this possibility inasmuch as a concurrence between canker development and response of the host to presence of the disease was found to exist. When, for example, inoculations were made in early autumn at a time trees were capable of burying affected areas beneath new tissue, as described in the first part of this section, small lesions resulted. If, on the other hand, inoculations were made in late autumn, when the trees had lost the ability to react to the disease, larger cankers developed. As we have seen, the results of inoculation throughout the two years reported herein (figs. 1,2 ) conform with those published earlier (16). In view of the coincidence between beginning of canker activity in autumn and loss by trees of their ability to produce periderm, records concerning stage of host development were kept each time the inoculations in figures 1 and 2 were made. In general these records show that larger cankers were secured from inoculations in autumn after the leaves had fallen than before leaf fall. In spring, maximum canker extension occurred sometime between the early blooming and first-leaf stages of the trees. The data concerning the first periderm formation in Duarte (table 6), the variety used in these inoculation tests, show that by early bloom stage this phenomenon was underway; that is, sometime before blossoms opened the trees regained their ability to produce periderm. The period between the time in autumn when the trees lost this ability and the time in spring when they regained it, corresponded roughly to the period when the disease may actively develop. Since data in figures 3 and 4 were interpreted to mean that some factor or factors tended to check canker extension even before the maximum springtime extension occurred, we may hypothetically assume that one factor, at least, was the regained ability of the host to produce periderm. Early in the spring, when the tree first begins to grow, the vigor of periderm formation is low ; but it increases as spring advances and as the trees come into leaf. Such a conception answers the requirements of the evidence that influence of the factor towards limiting canker extension becomes more profound as spring advances. The as- 
sumption that periderm may prevent extension of diseased areas presents nothing new. It has been investigated by Shaw (11) in the fire blight disease. This worker reports that the "cork layer" developing in advance of fire blight cankers appeared to prevent canker extension. When the layer was broken by mechanical means, cankers proceeded to extend even though they had previously ceased activity. Neither is the evidence presented herein, regarding activity of cankers during only certain parts of the year, unsupported by other workers. Wormald (19-22) could not obtain cankers of the cherry bacteriosis by inoculating in summer, but did obtain them when he inoculated at leaf fall (October or November). He further reports (20) that cankers stopped elongating in June.

If periderm causes waning canker activity in late spring and if, as shown earlier, phellogen activity depends upon growth of the tree as a whole, then cankers should cease activity earlier in those varieties which are first to begin growth in spring. Although no experimental evidence is at hand, the following observations are pertinent. Records taken in May, 1935 and 1937 (table 7), purported to show that cankers among trees of certain varieties differed with regard to the presence, absence, and relative number of dormant streaks. These streaks, it was found, were characterized by the fact that periderm had formed between the infected and the healthy tissues. More cankers in trees of early varieties possessed dormant streaks in considerable numbers than in trees of late varieties. In discussing the stages of canker activity (in the first section of this paper) the occurrence of dormant streaks was shown to indicate cessation of canker extension. Hence the data in table 7 may be regarded as evidence that by May a larger percentage of cankers were inactive in early than in late varieties.

To study more critically the connection between periderm formation and the waning of canker activity, numerous inoculations were made in May, 1937, into trees of Duarte plum, President plum, and Bing cherry, when the trees were in full leaf. The earlier experiments (figs. 3, 4) had indicated that cankers would develop more rapidly the first few days after inoculation than in subsequent days. To determine this point, 25 to 30 cankers were measured in each of the different species of trees 5,8 , 11, and 15 days after inoculation. At the same time pieces of bark at the apices of the cankers were taken for microscopic examination. To obtain a quantitative expression of periderm formation, freehand cross sections of the apices of 10 cankers were examined each time. The number of cells in the periderm, including the phellogen itself, were counted at several places around the invaded areas. This step was necessary because the layer did not develop uniformly on all faces of the canker : it frequently 
appeared on the inner face (nearest the cambium) sooner than on the outer face (nearest the cortex). It also appeared earlier at the sides than at the apical margins, particularly if the diseased area at this point had extended inward to the cambial zone. Since, however, the information desired concerned the time when phellogen appeared at the advancing apical margins, this region only was considered in compiling the data.

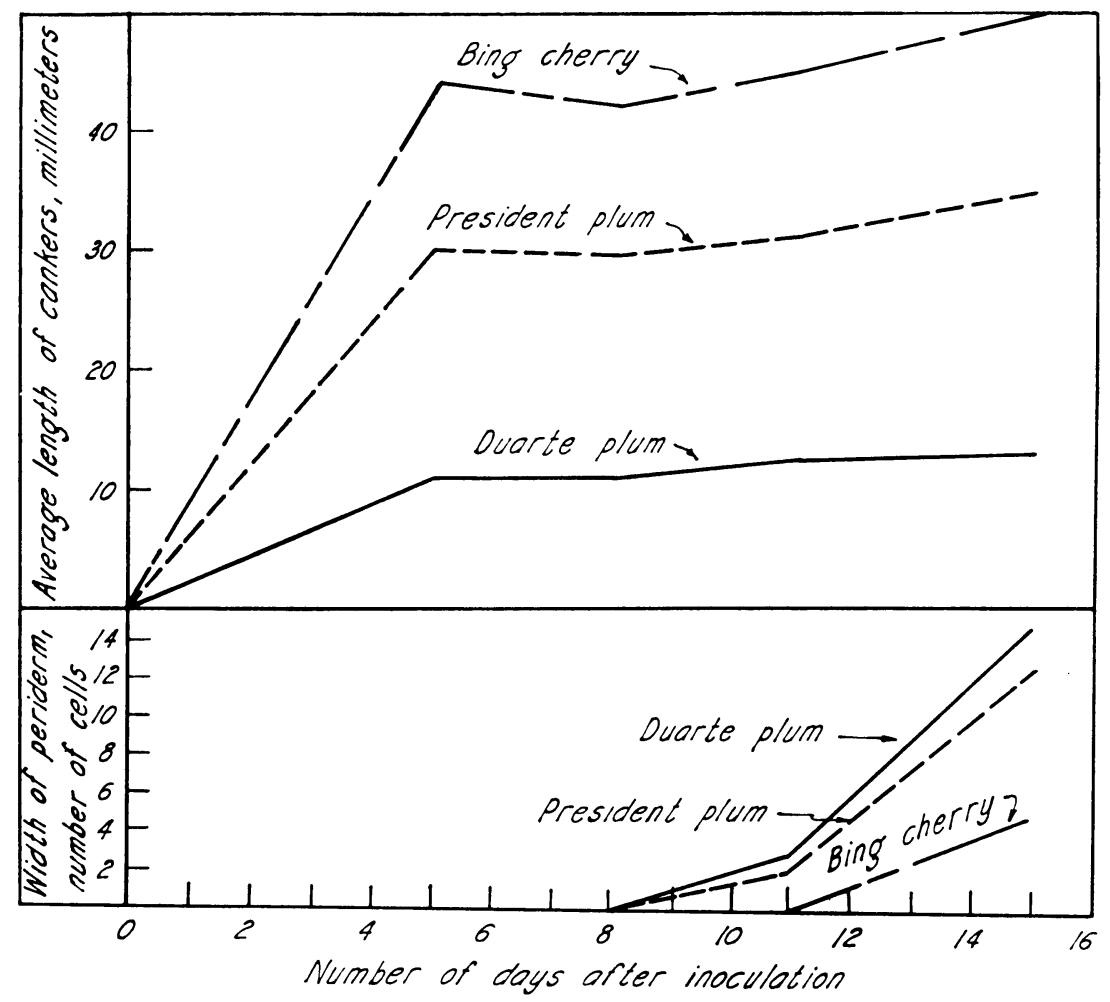

Fig. 9.-Comparison between canker enlargement and periderm formation in two varieties of plums and one variety of sweet cherry. Inoculations were made in May, 1937.

As with most former inoculations (fig. 6) the Duarte plum developed the smallest cankers, the President plum somewhat larger ones, and the Bing cherry the largest (fig. 9). Canker extension was very rapid in the three hosts during the first 5 days after inoculation, but very slow thence to the end of 15 days. These results accord well with those appearing in figures 3 and 4, wherein the rate of canker extension during the 10-day period after inoculation was more rapid than that for the second 10-day period. 
Whereas rate of canker extension suddenly decreased in the present experiments 5 days after inoculation, periderm formation was not observed in the plums until 8 to 11 days after inoculation, nor in the cherry until 11 to 15 days after inoculation. True, the relative amount of periderm formed in trees of the three species was roughly proportional to the size of cankers produced. We should not, however, consider this as proof that formation of this layer prevented canker extension, since (fig. 6) cankers developing in Duarte plum and Bing cherry varied in the same relation when inoculations were made in January, at a time when we should not expect periderm formation. Before concluding, however, that no causal relation exists between periderm formation and cessation of canker extension, we should not overlook the possibility that some change in the tissue destined to become meristemmatic might precede appearance of the phellogen, and that such a change might check canker extension.

\section{SUMMARY AND CONCLUSIONS}

Criteria, involving visible changes in the characteristics of the canker margin, have been developed to determine rise and fall in canker activity. By these criteria activity was seen to begin in late autumn, continue throughout winter and spring, and halt in early summer.

Increases and decreases of the bacterial population in affected tissue accompanied rise and fall in canker activity.

Marginal characteristics of the cankers, though denoting to some extent cankers that will or will not constitute oversummering sources for the bacteria, are not entirely reliable, since other factors influence survival of the bacteria in diseased tissue.

By inoculating trees at intervals throughout most of two years, it was found that the period in the autumn when cankers could be obtained corresponded with that during which naturally occurring established cankers began activity. Likewise the period in spring when cankers could no longer be obtained corresponded to the period during which naturally occurring established cankers cease activity. Apparently these data verify earlier conclusions that the enlargement of the diseased areas is confined to certain seasons of the year. A similar seasonal activity is typical also of the pear canker caused by the same organism.

Experiments were performed to determine how various factors, including those of the external environment and those within the trees, affect the activity of cankers. Low temperatures during midwinter were seen to result in decreased canker extension, whereas the rise of temperature in spring was accompanied by increased extension. The failure 
to obtain cankers by inoculating in early autumn and early summer was not, however, as far as the data warranted, attributable to adverse temperature. Especially, differences in rates of canker extension between two successive periods following inoculation could not be attributed to temperature differences. These data suggested that some factor began exerting an influence during the spring period when canker extension was at its maximum and that this influence became more pronounced as spring passed.

Moderately diseased trees growing on sandy loam soil were benefited by fertilization with ammonium sulfate. The benefit did not arise from increased resistance of trees to infection, nor apparently from increased resistance to extension of cankers through the tissues once infection was established, but seemingly from an enhanced ability of the tree to repair damages done by the disease.

Different soil-moisture conditions did not make trees growing in the field more or less favorable to progress of the disease. In tank experiments, however, where trees were located in soil lacking in available moisture- that is, soil in which the moisture had been reduced below the permanent wilting percentage-inoculations failed to induce cankers, whereas cankers were induced by inoculations into trees growing in soil with moisture above the permanent wilting percentage. The different results obtained in the two types of experiments are attributed to dissimilar conditions. That is, the orchard trees in the dry plots were probably never subjected to such extreme lack of available moisture as were trees in dry tanks, but may have been supplied with water by a few roots extending somewhat deeper than the 6-foot depth at which the samples were taken. The results can be interpreted as indicating that a lack of available soil moisture affected the disease adversely, whereas wide differences, short of an actual lack of available moisture, did not influence the disease. These studies by no means exhaust the possibilities of the problem as it relates to soil moisture.

Severity of the disease in a locality will be conditioned by the varieties grown. A few varieties are resistant, more are highly susceptible, but the greatest number are intermediate. Distinction is made between susceptibility to infection and susceptibility to inroads of the cankers once infection is established. One variety, the Duarte, classed as highly susceptible on the basis of tree mortality, proved consistently less favorable to progress of the cankers than another variety (President) which in two years suffered less from the disease. The former variety was highly susceptible to infection through buds, a situation apparently accounting for the high mortality of trees in certain years. 
Internal reactions of the host to presence of diseased areas were considered from the standpoint of possible effect on progress of cankers. These reactions are induced by (1) the vascular cambium, or at least by cells in that region, and (2) by a cork cambium or phellogen. Major aspects of development of the phellogen and resultant periderm around the diseased areas at canker margins are described. Relation of growth activity of the tree to periderm formation is considered. This and the similar, though probably not identical, phenomenon of callusing of wounded surfaces were shown to depend upon growth activity of the tree. Such varieties of plums as Beauty, Kelsey, Santa Rosa, and Duarte, that began growth early were found to develop periderm around diseased areas and callus at surfaces of wounds earlier than such varieties as President, Grand Duke, and Tragedy, that began growth late.

According to certain observational data, cankers in early-blooming varieties of plums (Beauty and Santa Rosa) stop activity earlier in spring than cankers in late-blooming varieties (President, Grand Duke, and Tragedy). Experimental data indicate a certain relation between occurrence of periderm and cessation of canker extension, but fail to prove that the periderm actually prevented canker activity. This point is worthy of much additional work. 


\section{LITERATURE CITED}

1. Beard, F. H., and H. Wormal.D.

1936. Bacterial canker of plum trees in relation to nutrition. Experimental results in sand culture. East Malling Res. Sta. Ann. Rpt. (Sect. III) 1936:146-54. (Appendix by W. A. Roach, p. 152-54.)

2. Brooks, A. N.

1926. Studies of the epidemiology and control of fireblight of apple. Phytopathology 16:665-96.

3. Conrad, J. P., and F. J. Veihmeyer.

1929. Root development and soil moisture. Hilgardia 4:113-34.

4. Hendrickson, A. H., and F. J. Veihmeyer.

1929. Irrigation experiments with peaches in California. Calfornia Agr. Exp. Sta. Bul. 479:1-56.

5. Hendrickson, A. H., and F. J. Veihmeyer.

1934. Irrigation experiments with prunes. California Agr. Exp. Sta. Bul. 573: $1-44$.

6. Marshall, R. P.

1931. The relation of season, of wounding, and of shellacking to callus formation. U. S. Dept. Agr. Tech. Bul. 246:1-29.

7. Miliser, P. W.

1929. Studies of fire blight of apple in Wisconsin. Jour. Agr. Res. 39:579-621.

8. Priestley, J. H.

1930. Studies in the physiology of cambial activity. III. The seasonal activity of the cambium. New Phytologist 29:316-54.

9. Priestley, J. H., and C. F. Swingle.

1929. Vegetative propagation from the standpoint of plant anatomy. U. S. Dept. Agr. Tech. Bul. 155:1-99.

10. Rosen, H. R.

1929. The life history of the fire blight pathogen, Bacillus amylovorus, as related to the means of overwintering and dissemination. Arkansas Agr. Exp. Sta. Bul. 244:1-96.

11. SHAW, Luther.

1934. Studies on resistance of apple and other rosaceous plants to fire blight. Jour. Agr. Res. 49:283-312.

12. Tulis, E. C.

1929. Studies on the overwintering and modes of infection of the fire-blight organism. Michigan Agr. Exp. Sta. Tech. Bul. 97:1-32.

13. Veihmeyer, F. J., and A. H. Hendrickson.

1934. Some plant and soil-moisture relations. Amer. Soil Survey Assoc. Bul. $15: 76-80$.

14. Veihmeyer, F. J., and A. H. Hendrickson.

1936. Essentials of irrigation and cultivation of orchards. California Agr. Exp. Sta. Cir. 50:1-24. (Revised 1936.) 
15. Wilson, E. E.

1931. A comparison of Pseudomonas prunicola with a canker-producing bacterium of stone-fruit trees in California. Phytopathology 21:1153-61.

16. Wilson, E. E.

1933. Bacterial canker of stone-fruit trees in California. Hilgardia 8:83-123.

17. Wilson, E. E.

1934. A bacterial canker of pear trees new to California. Phytopathology 24:534-37.

18. Wilson, E. E.

1936. Symptomatic and etiologic relations of the canker and the blossom blast of Pyrus and the bacterial canker of Prunus. Hilgardia 10:213-40.

19. WORMALD, $\mathrm{H}$.

1930. Bacterial diseases of stone-fruit trees in Britain. II. Bacterial shoot wilt of plum trees. Ann. Appl. Biol. 17:725-44.

20. Wormald, H.

1937. Bacteriosis of stone-fruit trees in Britain. VI. Field observations on bacteriosis of sweet cherry trees. Jour. Pomol. and Hort. Sei. 15:35-48.

21. WoRMaLd, H.

1937. Bacterial canker in plum and cherry trees. East Malling Res. Sta. Ann. Rpt. 1936:297-301.

22. WORMALD, H., and R. V. HARRIS.

1937. Notes on plant diseases in 1936. East Malling Res. Sta. Rpt. 1936:191-92. 